
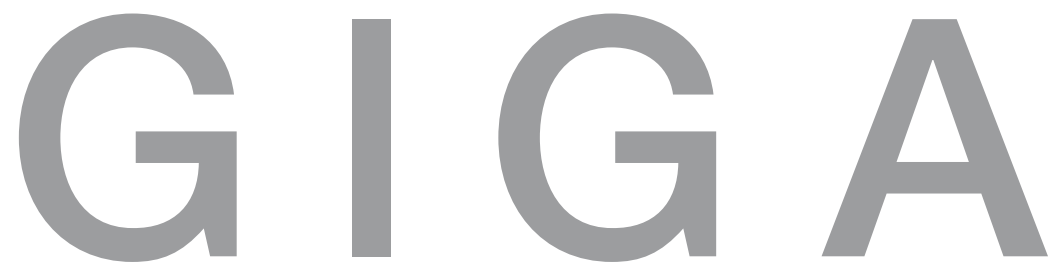

Working

German

Institute of Global and Area Studies Papers

Leibniz-Institut für Globale und Regionale Studien

GIGA Research Programme:

Violence, Power and Security

The Chinese Meaning of Just War and Its Impact on the

Foreign Policy of the People's Republic of China

Nadine Godehardt

$\mathrm{N}^{\circ} 88$

September 2008 


\section{GIGA Working Papers}

Edited by the

GIGA German Institute of Global and Area Studies

Leibniz-Institut für Globale und Regionale Studien

The Working Paper Series serves to disseminate the research results of work in progress prior to publication in order to encourage the exchange of ideas and academic debate. An objective of the series is to get the findings out quickly, even if the presentations are less than fully polished. Inclusion of a paper in the Working Paper Series does not constitute publication and should not limit publication in any other venue. Copyright remains with the authors. When Working Papers are eventually accepted by or published in a journal or book, the correct citation reference and, if possible, the corresponding link will then be included in the Working Papers website at <www.giga-hamburg.de/workingpapers>.

GIGA research unit responsible for this issue:

Research Programme: "Violence, Power and Security"

Editor of the GIGA Working Paper Series: Martin Beck<beck@giga-hamburg.de>

Copyright for this issue: (C) Nadine Godehardt

English copy editor: Melissa Nelson

Editorial assistant and production: Vera Rathje

All GIGA Working Papers are available online and free of charge on the website <www. giga-hamburg.de/workingpapers $>$. Working Papers can also be ordered in print. For production and mailing a cover fee of $€ 5$ is charged. For orders or any requests please contact: E-mail: workingpapers@giga-hamburg.de

Phone: ++49 (0)40 - 42825 - 548

The GIGA German Institute of Global and Area Studies cannot be held responsible for errors or any consequences arising from the use of information contained in this Working Paper; the views and opinions expressed are solely those of the author or authors and do not necessarily reflect those of the Institute.

GIGA German Institute of Global and Area Studies

Leibniz-Institut für Globale und Regionale Studien

Neuer Jungfernstieg 21

20354 Hamburg

Germany

E-mail: info@giga-hamburg.de

Website: www.giga-hamburg.de 


\title{
The Chinese Meaning of Just War and Its Impact on the Foreign Policy of the People's Republic of China
}

\begin{abstract}
The image of China's peaceful rise, which the Chinese government is keen to enforce in the world, stands in contrast to the view of China's ascent as a threat. China's economic and military growth is perceived as a potential threat to the (East) Asian security structure and as a challenge to the preponderance of the United States. Even though the PRC is more active in international and regional organizations - and better integrated in the international community - than ever before, the ambiguity of China's true political intentions is still dominant.

The focus of this analysis is the Chinese tradition of Just War and its benefits for an enhanced understanding of contemporary Chinese foreign policy. The tradition of Just War has rarely been studied, but the search for an understanding of Just War in Chinese traditional thinking can, nevertheless, assist in the analysis of China's current foreign policy. Whether China's foreign policy is benign or malignant or whether China dominates Asia is, therefore, "profoundly uncertain." With regard to foreign policy analysis, the differentiation between the regional and the international levels might help to transcend the predominant understanding of Chinese foreign policy in international relations theory.
\end{abstract}

Keywords: China's foreign policy, Just War theory, Confucianism, harmonious world

\section{Nadine Godehardt}

is a political scientist, a Ph.D. candidate at the University of Hamburg and GIGA, and a member of GIGA's Regional Powers Network (RPN).

Contact: godehardt@giga-hamburg.de

Website: http://staff.giga-hamburg.de/godehardt 


\section{Zusammenfassung}

\section{Das chinesische Verständnis vom gerechten Krieg und der Einfluss auf die}

\section{Außenpolitik der VR China}

Das Bild vom friedlichen Aufstieg Chinas, das von der chinesischen Regierung verbreitet wird, steht im Gegensatz dazu, dass Chinas wirtschaftlicher und militärischer Aufstieg als mögliche Bedrohung für die Sicherheitsstruktur (Ost-)Asiens und als Herausforderung der US-amerikanischen Vorherrschaft betrachtet wird. Obwohl die VR China noch nie so aktiv in der internationalen Gemeinschaft war wie heute, besteht Unsicherheit bezüglich ihrer wahren politischen Absichten.

Der vorliegende Beitrag untersucht die chinesische Tradition des gerechten Krieges, um ein erweitertes Verständnis von der gegenwärtigen chinesischen Außenpolitik zu gewinnen. Die Vorstellung vom gerechten Krieg ist bisher nur selten untersucht worden, dennoch kann es die Analyse der gegenwärtigen chinesischen Außenpolitik bereichern, die bereits im alten China vorliegenden entsprechenden Ideen einzubeziehen. Die Auseinandersetzung mit dem chinesischen Verständnis vom gerechten Krieg und mit dessen Anwendung auf Chinas Außenpolitik sensibilisiert zudem dafür, zwischen verschiedenen Ebenen der Analyse zu unterscheiden. So kann die Differenzierung zwischen regionaler und internationaler Ebene helfen, das vorherrschende Verständnis von der chinesischen Außenpolitik in den internationalen Beziehungen zu transzendieren. 


\title{
The Chinese Meaning of Just War and Its Impact on the Foreign Policy of the People's Republic of China
}

\author{
Nadine Godehardt
}

\section{Article Outline}

1 Introduction

2 The Concept of War in China: Cultural Moralism vs. Cultural Realism

3 The Chinese Tradition of Just War: Confucianism and Military Strategists

4 General Characteristics of Just War in the Chinese Tradition

5 Just War in a Harmonious World: Implications of a Traditional Concept for Contemporary Chinese Foreign Policy

6 Conclusion

\section{Introduction}

The determining principles of Chinese foreign policy at the beginning of the twenty-first century are, amongst others, peace, development, and cooperation (heping, fazhan, hezuo). ${ }^{1}$ Although promoting peace is a universal goal, hardly any state emphasizes its peaceful and defensive orientation as definitely as the People's Republic of China (PRC). ${ }^{2}$

The concept of a harmonious society (hexie shehui) further highlights the constant significance of economic success and the general political direction in China. A harmonious Chinese society

1 See as one example the official statement of the Ministry of Foreign Affairs of the People's Republic of China: Peace, Development and Cooperation. In Commemoration of the 35th Anniversary of Restoration of Lawful Seat of the People's Republic of China in the United Nations, 2006, www.fmprc.gov.cn/ng/wjb/zzjg/gjs/gjsxw/t278484. htm, last accessed on 4 December 2007. Li Zhaoxing: Peace, Development and Cooperation. Banner for China's Diplomacy in the New Era, 08/2005, www.fmprc.gov.cn/eng/zxxx/t208032.htm, last accessed on 4 June 2008.

2 See official statements about the Chinese policy of peace and development and harmonious society 中国的和平发 展道路 (China's Way of Peace and Development), www.gov.cn/zwgk/2005-12/22/content_134060.htm, last accessed on 6 June 2008; and for more detailed information about harmonious society and government innovations see, for example, www.china.com.cn/aboutchina/zhuanti/hxsh/node_7043253.htm, last accessed on 6 June 2008. 
can only be accomplished in agreement with a peaceful and stable international environmenta harmonious world (hexie shijie). ${ }^{3}$ Domestic stability, therefore, describes the foundation of China's new "going out" mentality, which "marks a shift in the leadership understanding of China's position in the world." ${ }^{4}$ China's "new role" is not only being carefully monitored by other great and regional powers, but is also widely discussed in the academic debate. ${ }^{5}$

The image of China's peaceful rise, which the Chinese government is keen to enforce in the world, stands in contrast to the view of China's ascent as a threat. China's economic and military growth is perceived as a potential threat to the (East) Asian security structure and as a challenge to the preponderance of the United States. ${ }^{6}$ The uncertainty about China's true military capabilities and political intentions additionally supports the image of a "dangerous" China. ${ }^{7}$ Even though the PRC is more active in international and regional organizations - and better integrated in the international community - than ever before, the ambiguity of China's true political intentions is still dominant. Domestically, the drastic measures taken against the so-called three evils, fundamentalism, separatism, and terrorism, have stoked distrust of China's peaceful rise. ${ }^{8}$ The questions of Taiwan, Tibet, and Xinjiang are the most definite challenges for the Chinese authorities, but the political solutions to the Xinjiang, Tibet, or Taiwan problems differ from the proclaimed principle of peaceful development.

In the theoretical debate, offensive realists have decisively influenced the discussion and have emphasized the possibility of a coming conflict between China and the United States. ${ }^{9}$ From their perspective, China is a revisionist state like all great powers and seeks hegemony in the system. ${ }^{10}$ In contrast, Alastair Iain Johnston states that China is increasingly conforming to international and regional norms, and for that reason China is not a revisionist

3 See Lam, Willy: Socialism with a Harmonious Face: Hu Jintao's Plan for Reform, in: China Brief, Vol. 4, No. 20 (2004), pp. 5-7; Harmonious Society, in: China Daily, 29 September 2007, http://english.peopledaily.com.cn/ 90002/92169/92211/6274603.html, last accessed on 5 December 2007.

4 Zheng, Yongniang/Sow Keat Tok: Harmonious society and harmonious world: China's policy discourse under Hu Jintao, in: Briefing Series (University of Nottingham), p. 1.

5 Christensen, Thomas J.: Posing Problems without Catching Up. China's Rise and Challenges for U.S. Security Policy, in: International Security, Vol. 25, No. 4 (2001), pp. 5-40; Gill, Bates/Yanzhong Huang: Sources and Limits of Chinese 'Soft Power', in: Survival, Vol. 48, No. 2 (2006), pp. 17-36; Medeiros, Evan/Fravel, Taylor: China's New Diplomacy, in: Foreign Affairs, Vol. 82, No. 6 (2003), pp. 22-35.

6 For a critical discussion of the China threat theory see Khalid R. Al-Rodhan: A Critique of the China Threat Theory: A Systematic Analysis, in: Asian Perspective, Vol. 31, No. 2 (2007), pp. 41-66.

7 "[...] much uncertainty surrounds China's future course, in particular in the area of its expanding military power and how that power might be used," see Annual Report to Congress: Military Power of the People's Republic of China 2008; all reports from 2002 to 2008 available at: www.defenselink.mil/pubs/china.html, last accessed on 12 August 2008. Even in public surveys, China's popularity has declined in the Olympic year, especially since the civil protest in Tibet. US: 2007 42\%, 2008 39\%; Britain: 2007 49\%, 2008 47\%; Spain 2007 39\%, 2008 31\%; France 2007 47\%, 2008 28\%, Germany 2007 34\%, 2008 26\%. The PEW Global Attitudes Project: Global Economic Gloom-China and India Notable Exceptions, June 2008, http://pewglobal.org/reports/pdf/ 260.pdf, last accessed on 8 August 2008.

8 See Chung Chien-peng: Confronting Terrorism and Other Evils in China: All Quiet on the Western Front?, in: The China and Eurasia Forum Quarterly, Vol. 4, No. 2 (2006), pp. 75-87.

9 Bernstein, Richard/Munro, Ross H.: China 1: The Coming Conflict with America, in: Foreign Affairs, Vol. 76, No. 2 (1997), pp. 18-32.

10 Mearsheimer, John: The Tragedy of Great Power Politics, New York 2001, p. 21. 
power. ${ }^{11}$ Whether China's foreign policy is benign or malignant and whether China dominates Asia is, therefore, "profoundly uncertain."12 Thus, on the regional and international level, the question of whether China is a status quo power or a revisionist state has not yet been answered satisfactorily.

But what are the causes of war, and under which circumstances is war justified? Although the Chinese understanding of Just War has rarely been studied, ${ }^{13}$ the investigation of the idea of Just War in Chinese traditional thinking can, nevertheless, contribute to the analysis of China's current foreign policy. In this context, the Chinese concept of Just War must be analyzed with respect to the understanding of political order in traditional China, which mainly centered on an ideal emperor who held the Mandate of Heaven and whose power knew no boundaries. The examination of the Chinese understanding of Just War and its application to China's foreign policy might highlight the usefulness of different levels of analysis. With regard to contemporary foreign policy analysis, the differentiation between the regional and the international level might help to transcend the predominant understanding of Chinese foreign policy in international relations theory.

The focus of this analysis is the Chinese tradition of Just War and its benefits for an enhanced understanding of contemporary Chinese foreign policy. Thus, I aim to derive deeper insight into current patterns of Chinese foreign policy from the Chinese understanding of Just War. Although my perspective is limited to only one aspect of the tremendously vast Chinese culture, the underlying questions are also essential for political theorists. ${ }^{14}$ Consequently, an empirical examination of China's actual participation in warfare is not of interest; rather, I analyze the classical writings of Chinese philosophy in order to understand the general characteristics of Just War in the Chinese tradition. The Chinese meaning of Just War is examined by means of philosophical texts from the Spring and Autumn Period as well as

11 Johnston, Alastair I.: China as a Status Quo Power?, in: International Security, Vol. 27, No.4 (2003), pp. 5-56.

12 Friedberg, Aaron L.: The Future of U.S.-China relations. Is Conflict inevitable?, in: International Security, Vol. 30, No. 2 (2005), p. 8. As Aaron Friedberg, one of the leading US experts on Chinese foreign policy, said: "Our host, [...], have asked us to debate the question of whether China seeks to dominate Asia and in fact to reduce or push out the United States. My short answer to this question is, I don't know, [...]." See Carnegie Endowment for International Peace: Reframing China Policy. China's Strategic Objectives in Asia. Discussion with Aaron Friedberg and Robert Sutter (Moderator: Michael Swaine), 2007, www.carnegieendowment.org/ files/debate_five.pdf, last accesssed 6 June 2008.

13 Most of the examinations deal with Chinese warfare and the meaning of war in general. Some examples of a specific analysis of the Just War problematic are Bell, Daniel A.: Just War and Confucianism. Implications for the Contemporary World, in: Bell, Daniel A. (ed.): Confucian political ethics, Princeton 2007, pp. 226-257; Lewis, Mark E: The Just War in Early China, in: Brokke Torkel (ed.): The Ethics of War in Asian Civilizations, London/New York 2006, pp. 185-200; Lewis, Mark E.: Sanctioned Violence in Early China, Albany New York 1990; Turner, Karen: War, Punishment and The Law of nature in Early Chinese Concepts of the State, in: Harvard Journal of Asiatic Studies, Vol. 53, No. 2 (1993), pp. 285-324; 吴征宇 (Wu Zhengyu): 正义战争理论的当代意义论 析 (Contemporary Meaning of the Just War Theory), in: 现代国际关系 (Contemporary International Relations), No.8 (2004), pp. 12-17; 张露 (Zhang Lu): 中西正义战争思想比较分析 (A Comparison between Chinese and Western Just War Thought), in: 现代国际关系 (Contemporary International Relations), No. 4 (2005), pp. 15-20.

14 For instance, Kenneth W. Waltz tries to answer the question regarding the causes of war and peace. See Waltz, Kenneth N.: Man, the state and war. A Theoretical Analysis, New York 2001 [1959]. With a broader focus on security, see also Buzan, Barry: People, States and Fear: an agenda for international security in the post-cold war era, 2nd edition, New York 1991. 
the Warring States Period (722 B.C.-221 B.C.). The writings of interest are the Confucian classics, Confucius, Mencius, and Xunzi, as well as the seven military classics. ${ }^{15}$ The current policy of a harmonious society/world (hexie shehui/hexie shijie) also refers to these writings. Although classic writings constitute only one aspect of the official discourse in China (alongside, for instance, Maoist thought), it is still necessary to take this aspect seriously. ${ }^{16}$

\section{The Concept of War in China: Cultural Moralism vs. Cultural Realism}

\section{1 “Cultural Moralism"17}

The Western and Chinese secondary literature generally emphasizes the unimportant role of military force in Chinese tradition. ${ }^{18}$ John K. Fairbank, for instance, states that in China war was and is to be considered as a last resort. ${ }^{19}$ Thus, the use of force shall only be justified if neither the classical Confucian teachings nor the practice of rewards and punishment ${ }^{20}$ are successful. Otherwise, in the past, the use of force simply displayed the moral weakness of the emperor, and he would loose the Mandate of Heaven. The Mandate of Heaven was the symbol of the emperor's authority in traditional China. It constituted the core of the Chinese traditional understanding of state. As Herlee G. Creel emphasizes,

The doctrine of the Mandate of Heaven became the cornerstone of the Chinese Empire. Henceforward China was a state-and, since it ideally embraced "all under heaven", the only state - created by, and maintained under the direct supervision of, the highest deity, Heaven. Its ruler was the Son of Heaven. His office bestowed the highest lorry [sic] possible to man. ${ }^{21}$

15 Sawyer, Ralph D.: The Seven Military Classics of Ancient China (transl. by Ralph D. Sawyer with Mei-chün Sawyer), Boulder/San Francisco/Oxford 1993; Sun Pin: Military Methods (transl. by Ralp D. Sawyer with Meichün Sawyer), Boulder/San Francisco/Oxford 1995. Confucius: Analects of Confucius, Beijing 1994; Hsüntzu (transl. by Hermann Köster), Kaldenkirchen 1967. 孟子 (Mengzi), in: 陈成国 (Chen Chengguo): 四书五经 (Four Books and Five Classics) (Vol. 1), Hunan Changshao 2002, pp. 61-139.

16 For a recent analysis of the official discourse see Billioud, Sébastien: Confucianism, "Cultural Tradition", and Official Discourse in China at the start of the New Century, in: China Perspectives, Vol. 69, No 3 (2007), pp. 5065. The central meaning of Confucius for traditional and contemporary China was also emphasized during the opening ceremony of the Olympics 2008 (08.08. 2008) in Beijing. In particular, the importance of the character he was pointed out.

17 This phrase has been introduced by Tiejun Zhang. His concept of "cultural moralism" refers to Confucian ideas and stands in contrast to Alastair I. Johnston's "cultural realism." See Zhang, Tiejun: Reconstruction the Great Wall. Chinese Security Strategy in the Early 21 ${ }^{\text {st }}$ Century, Goteborg 2003, p. 32.

18 For an overview of the central literature see Johnston, Alastair I.: Cultural Realism. Strategic Culture and Grand Strategy in Chinese History, Princeton 1995, pp. 62-65 and also Swaine, Michael D./Tellis, Ashley J.: Interpreting China's Grand Strategy. Past, Present, and Future (Project Air Force RAND), Santa Monica 2000, p. 45.

19 Fairbank, John K: Introduction: Varieties of the Chinese Military Experience, in: Kiermann, Frank A./Fairbank, John K. (ed.): Chinese Ways in Warfare, Cambridge Mass. 1974, pp. 1-26.

20 "Rewards and Punishment" was introduced by the Legalists (fajia), who represent the realist strand of Chinese philosophy. The concept implies that the emperor should use rewards or punishments towards his people according to the circumstances. In a broader sense, "Rewards and Punishments" underlines the flexibility of Chinese criminal law.

21 Creel, Herlee G.: The Origins of Statecraft in China (Vol. 1). The Western Chou Empire, Taipei 1970, p. 93. 
The emperor represented the highest level of morality, and because of his virtuousness he held the Mandate of Heaven. The emperor further symbolized the unity of harmony and stability within the political order. His own moral behavior coincided with his own personality, and, as a result, the emperor's virtue was recognized beyond the country's boundaries. The acceptance of his authority by others was the essential reason why war was no longer necessary. If the emperor, therefore, held the Mandate of Heaven, his virtuousness was a reason for the insignificance of military force and war, but if the emperor was forced to wage a war, it then proved that he could not preserve the harmony of his nation and between nations. Fairbank concludes, "Herein lies the pacifist bias of the Chinese tradition. War is not easy to glorify because ideally it should never have occurred." ${ }^{22}$ This also shows the difficulty of identifying the Chinese concept of war. According to most authors war is prohibited in Chinese tradition. For instance, Adelmann and Shih mention that "war was seen as an aberration."23 Similar to Fairbank, Adelmann and Shih emphasize the pacifist focus of the Chinese war concept. They stress two aspects in particular that are in contrast to the West. ${ }^{24}$ Firstly, that nonviolent solutions are preferred to direct confrontations. Secondly, that there exists a general preference for defensive warfare; wars of aggression are morally condemned.

Due to these two aspects, psychological warfare has a higher significance than physical warfare or bloodshed. The authors furthermore compare Chinese warfare with an art and confront the "war as art" with the Western understanding of "war as tactics." According to this idea, victory is not gained through violence but through stratagem. ${ }^{25}$

Adelmann and Shih focus primarily on the question of how war is waged, and they conclude that the means of war are intended to avoid the use of military force. This justifies their argument that from a Chinese perspective violence and war are condemned and outlawed ("war was seen as an aberration"). From the question of how war is waged, Adelmann and Shih draw their conclusion about the general meaning of war. But this argumentation raises the following criticism.

Adelmann and Shih's analysis responds the question of whether war (or violence) is part of the Chinese military tradition. They identify the idea of psychological warfare-which basically means war is war without fighting ("victory by stratagem, not force") - as the greatest difference from the West. Like that of Fairbank, Adelmann and Shih's argumentation attempts to develop a pacifist idea of war, but this pacifist doctrine cannot explain the fact that even in China war is possible. This is probably why Adelmann and Shih chiefly examine Chinese strategic thinking, which was founded by the military strategists, especially Sunzi. For Sunzi, however, the use of force constitutes a real option. But under which circumstances is the use of force justified? The hiatus which arises at this point and which is not sufficiently explained with reference to defensive warfare is the question regarding the justi-

22 Fairbank: Introduction, p. 7.

23 Adelmann, Jonathan R./Chih-yu Shih: Symbolic War: The Chinese Use of Force. 1840-1980, Taipei 1993, p. 31.

24 See here and in the following Adelmann/Shih: Symbolic Wars, p. 32.

25 Adelmann/Shih: Symbolic Wars, p. 33. 
fication of war. This question stands at the beginning of this analysis and considerations regarding successful strategy follow - not vice versa.

\subsection{The Realists: Alastair I. Johnston and Andrew Scobell}

Since the mid-1990s the pacifist view of China's military tradition as argued by Fairbank and others has frequently been challenged. Because if this pacifist and defensive orientation describes the guidelines and characteristics of Chinese security policy up to the present day, and if further, as according to Andrew Scobell, this characteristic means that only the Chinese civilization is peaceful, ${ }^{26}$ then the question of how the Chinese government explains an antisecession law that implies the possibility of war against Taiwan is a legitimate one. ${ }^{27}$ China's self-perception as a peace-loving nation, in contrast to foreign perceptions of the country, has not changed much. Various factors, such as the ongoing economic boom, increasing political engagement, and military armament, have fueled the US-led discussion of China as a "strategic threat." ${ }^{28}$ Alastair I. Johnston and Andrew Scobell use this distrust as the starting point for their analysis.

\subsubsection{Alastair I. Johnston's “Cultural Realism"}

In the book Cultural Realism Alastair I. Johnston explores the actual use of force in Chinese military thought. His central question is, "How does one explain the frequency of violence in Chinese historical strategic behaviour while at the same time maintaining that traditional Chinese strategic thought is uniquely antimilitaristic?" ${ }^{29}$ As a result, Johnston mentions two requirements for the development of strategic thinking in China: on the one hand a Confucian, pacifist orientation and on the other the so-called Parabellum ${ }^{30}$ paradigm, which refers to the Western concept of Realpolitik. Johnston chooses a dichotomous approach to study

26 Andrew Scobell refers to the Chinese Defense White Paper in 1998, but in the 2004 version there are similiar statements. See Scobell, Andrew: The Chinese Cult of Defense, in: Issues and Studies, Vol. 37, No. 5 (2001), p. 115. In the Chinese scientific debate the connection between current policy and traditional thinking describes a basic approach. See 罗建波 (Luo Jianbo): 构建中国崛起的对外文化战略 (Establishing an external cultural strategy currently rising in China), in: 现代国际关系 (Contemporary International Relations), No. 3 (2006), p. 36.

27 See Anti-Secession law Art. 8: "[...] the state shall employ non-peaceful means and other necessary measures to protect China's sovereignty and territorial integrity. The State Council and the Central Military Commission shall decide on and execute the non-peaceful means and other necessary measures as provided for in the preceding paragraph and shall promptly report to the Standing Committee of the National People's Congress."

28 See Roy, Denny: Hegemon on the Horizon? China's Threat to East Asian Security, in: International Security, Vol. 19, No. 1 (1994), pp. 149-168; Christensen, Thomas J.: Chinese Realpolitik, in: Foreign Affairs, Vol. 75, No. 5 (1996), pp. 37-52 and more recently Christensen, Thomas J.: Posing Problems without Catching Up. China's Rise and Challenges for U.S. Security Policy, in: International Security, Vol. 25, No. 4 (2001), pp. 5-40. As an example of the Chinese discourse see 楼春豪(Lou Chunhao): 进攻性现实主义“中国威胁论”的实质 (The Essence of the Offensive Realism View on the "China Threat Debate"), in: 国际关系学院研究生部 (Journal of University of International Relations), No. 3 (2006), pp. 14-18.

29 Johnston, Alastair I.: Cultural Realism. Strategic Culture and Grand Strategy in Chinese History, Princeton 1995, p. 27.

30 Parabellum means "si pacem, parabellum" (Engl.: If you seek peace, prepare for war.), see Johnston, Alastair I.: Cultural Realism and Strategy in Maoist China, in: Peter J. Katzenstein (ed.): The Culture of National Security: Norms and Identity in Word Politics, New York 1996, p. 217, fn. 2. 
Chinese strategic culture. ${ }^{31}$ He focuses on the Song dynasty's collection of military classics, because in his opinion it is important to search for the earliest transcripts in Chinese history where the idea of strategic culture was elaborated. ${ }^{32}$ Johnston examines these Chinese military classics and questions their pacifist bias, which other authors (Fairbank, Adelmann/Shih) often imply a priori.

Based on three general elements of strategic culture, ${ }^{33}$ Johnston distinguishes the central paradigm of a Chinese strategic culture as follows: firstly, the condition of war shall be condemned and avoided; secondly, the enemy shall be cultivated; and thirdly, force is only used as a last resort. If armed force has to be used against external security threats, it should generally be defensive. Johnston draws the conclusion that force is not respected as an effective instrument and is quite contrary to a moral and virtuous basis for the domestic political system, which in turn leads to a peaceful society. But in view of the military strategists, Johnston reconsiders:

In the military texts the use of the military instrument (bing 兵) is considered highly efficacious, indeed necessary, for dealing with security threats. This is not to say that war or violence is the sole basis of the state security, but there is a strong expectation that violence inheres in human social processes, [...]. Thus the status of violence in these texts is higher than implied in the secondary Western and Chinese literature. It is also higher than implied in the Confucian-Mencian notion of internal rectification as the basis for external security that infuses much of this secondary literature."34

Johnston opposes the pacifist doctrine with a realist approach which characterizes the use of force as a social phenomenon. Thus, Johnston joins realism with Chinese culture. This forgotten connection is one of his greatest achievements.

As important as the confrontation of the Confucian (moral) approach with the realist ideas of the military strategists is, their relation is not finally resolved. Moreover, the question arises as to what the dichotomy of Chinese strategic culture actually demonstrates, since elements of the moral viewpoint are also recovered in the realist ones. ${ }^{35}$ Johnston's dichotomy explains only that from a Confucian perspective the use of force is considered ineffective and from a military strategist perspective seems to be effective. This merely underlines the fact that war in China also describes a social phenomenon, and it is furthermore another

31 Johnston speaks of the "dichotomized nature of Chinese strategic culture." Johnston: Cultural Realism, p. 173.

32 Johnston: Cultural Realism, p. 40. Johnston states that he only needs to analyze the military classics, because these works already comprehend elements of other traditions (e.g., Confucianism, Legalism or Daoism), see Johnston: Cultural Realism, p. 45: "Indeed, there is in some cases very little difference between the content of these military classics and the other texts on statecraft that have been traditionally categorized as philosophical classics." See also Johnston, Alastair I.: Thinking about Strategic Culture, in: International Security, Vol. 19, No. 4 (1995), pp. 32-64.

33 The three general elements are the role of war within human relations, the nature of the enemy, and the effectiveness of military violence. For a comprehensive introduction of "strategic culture" see Johnston: Cultural Realism, p. 5-31; 37.

34 Johnston: Cultural Realism, p. $72 \mathrm{f}$.

35 See Johnston: Cultural Realism, p. 66: "Most of the texts [the military classics, N.G.] repeat in various forms the statement that weapons are inauspicious instruments and are only used under unavoidable circumstances." 
response to the question-although from a realist perspective- of whether war or force generally plays a role in Chinese tradition.

The discussion of Just War ${ }^{36}$ further demonstrates how difficult it is to identify the meaning of Just War within this dichotomous approach. Consequently, Johnston uses the concept of Just War to highlight Chinese zero-sum politics ${ }^{37}$ and misses the opportunity to explain the correlation between these two approaches. Although he discovers that for the military strategist, as for the Confucian writers, war sometimes is necessary, Johnston has difficulty understanding why war as a political instrument is condemned but then under unavoidable circumstances also justified.

Most of the contradictions in Johnston's argumentation are related to his insufficient examination of Just War theory. The dimensions of the European concept of Just War can be introduced with the help of the following two questions: firstly, when or under which circumstances is war acceptable (jus ad bellum)? Secondly, how is the justified war waged (jus in bello)? ${ }^{38}$ The realist aspect of a Just War is that war is not categorically negated but sometimes possible. With respect to the military strategists, the justification of war is already resolved, as Johnston himself points out. ${ }^{39}$ Thus, the topic of these classics is more related to the question of how a Just War actually has to be waged (jus in bello). It is, therefore, less important that violence plays a more central role for the military strategist than for the Confucians and more important to determine how the use of force or the means of war are judged. This basic distinction of Just War could have shed some light on Johnston's attempt to correlate a Confucian approach with a realist one.

\subsubsection{Andrew Scobell's "Cult of Defense"}

In his book China's Use of Military Force. Beyond the Great Wall and the Long March, ${ }^{40}$ Andrew Scobell clearly opposes Johnston's concept of cultural realism. He argues that Johnston primarily pursues a unilateral approach because he mainly considers the Chinese military classics; Johnston's realist view of Chinese strategic culture represents his central aspect of analysis. Scobell further argues that Johnston underlines the symbolic character of Confucianism only within Chinese military tradition. ${ }^{41}$ In contrast to this unilateral approach, Sco-

36 Johnston mostly speaks of "righteous war" (Chin. 义战, yizhan), but the connection to the Just War theory is obvious. Besides, other scientists translate the Chinese term "yizhan" as Just War, and the explicit difference between the two phrases is not explained by Johnston.

37 See Johnston: Cultural Realism, p. 71.

38 A third perspective is the termination of war (or jus post bellum) For a comprehensive overview see OREND, Brian: Jus Post Bellum, in: Journal of Social Philosophy, Vol. 31, No. 1 (2000), pp. 117-137; Davida, Kellog E.: Jus post Bellum: The Importance of War Crime Trials, in: Parameters, Vol. 32, No. 3 (2002), pp. 87-99; Orend, Brian: The Morality of War, Toronto 2006. Waler, Michael: Just and Unjust Wars. A Moral Argument with Historical Illustrations, 3rd edition, New York 2003.

39 See Johnston: Cultural Realism, p. 68: "Indeed, in the military texts, the only conditions under which force can be legitimately employed is to fight a 'righteous war' (yi zhan 義戰) [...]."

40 Scobell, Andrew: China's Use of Military Force. Beyond the Great Wall and the Long March, Cambridge 2003.

41 Scobell: Use of Military Force, p. 20: "Yet Johnston seeks to explain away the presence of a 'ConfucianMencian' strand in strategic writings." 
bell emphasizes "that both strands of strategic culture are operative, and that the 'Confucian-Mencian" one reflects deeply held beliefs ${ }^{\prime 42}$.

Scobell highlights a close link between the Chinese tradition of criminal law and the present defense policy. According to Scobell, Chinese criminal law refers to two different schools of thought, namely Confucianism and legalism. ${ }^{43}$ Scobell therefore concludes that a dualistic argumentation is essential for the analysis of Chinese strategic culture. He states, "If China's criminal justice policy has historically been shaped by the interplay between two divergent philosophies, then surely this is also possible in the case of defence policy." 44 Using both philosophical traditions, Scobell adopts his understanding of a Chinese strategic culture, which he describes as "Cult of Defense." His central questions are as follows:

Is China a peaceful, defensive-minded power or a bellicose, expansionist state? Has China become more belligerent in recent decades? How can contemporary depictions of a bellicose China be reconciled with earlier descriptions of a dominant pacifist tradition ${ }^{45}$

In contrast to the "Cult of Offensive" which was pursued by the European elite during the First World War, the "Cult of Defense" is rooted in the cultural-not ideological-tradition of China. Scobell's "Cult of Defense" is paradoxical, because it includes not only defensive measures but also offensive actions. "Moreover, the effect of the present 'Cult of Defense' is, paradoxically is not a preference for what are clearly defensive military policies and actions but rather those that are actually offensive." ${ }^{46}$ This understanding of defense policy, which actually implies offensive military strikes, coincides with the ambiguous Chinese political rhetoric. It shows that the concept of defense is used flexibly, and basically points out the pragmatic perception of defense in China.

Scobell's "Cult of Defense" consists of "three core philosophical elements and four guiding strategic principles." ${ }^{47}$ The former make up the central elements of Chinese military tradition, which also represent the Confucian tradition: firstly, the Chinese are peace-loving people; secondly, they are not aggressive or expansionist; thirdly, they use force only in the case of self-defense. The latter four guiding principles underline the fact that China (1) fights only Just Wars, (2) values national unity, (3) is surrounded by domestic and foreign enemies, and (4) adheres to the concept of "active defense." ${ }^{48}$ In contrast to the three core elements, these four guiding strategic principles justify the use of force. However, Scobell does not quote

42 Scobell: Use of Military Force, p. 20

43 Legalism (Chin. 发家fajia) is a Chinese philosophical school which deduces its ideas from the political praxis during the Warring States Period. Hence Legalist ideas stand in direct opposition to Confucian ones. The most important representatives are Shang Yang and Han Feizi. For further information see SHANG YANG: The Book of Lord Shang. A Classic of the Chinese School of Law (transl. by Duyvendak), London 1928. HAN FEIZI: Die Kunst der Staatsführung. Die Schriften des Meisters Han Fei (transl. by Wilmar Mögling), Leipzig 1994.

44 Scobell: Use of Force, p. 22.

45 Scobell: Use of Force, p. 15.

46 Scobell: Use of Force, p. 26.

47 See here and in the following Scobell, Andrew: The Chinese Cult of Defense, in: Issues \& Studies, Vol. 37, No. 5 (2001), pp. 100-127.

48 Scobell: The Chinese Cult of Defense, p. 113. 
any background which explains the central idea of his "Cult of Defense." Even though he emphasizes the usage of Just War from Confucius to Mao Zedong, he cannot document the specific Confucian aspect in the Chinese concept of Just War. He examines current military confrontations between China and other countries, but his empirical case studies cannot disprove Johnston's hermeneutic cultural realist approach.

In addition, Scobell does not deal with the different dimensions of Just War. Firstly, the (European) idea and origin of Just War is not introduced. Representatives of the European concept of Just War-traditional as well as modern ones - distinguish between three dimensions of Just War: the justice to war (jus ad bellum), laws concerning practices while engaged in a war (jus in bello), and justice after war (jus post bellum). Each of these dimensions highlights a specific question of Just War, and only if all conditions are fulfilled can a war be called a Just War. ${ }^{49}$ Secondly, the way in which the Chinese understand the different dimensions of Just War remains uncertain. Thirdly, Scobell avoids distinguishing the originally Chinese meaning of Just War from the political rhetoric used in his case studies (such as the Chinese involvement in Vietnam). Scobell's conclusion regarding the common role of Just War within current Chinese politics is questionable. Because if, as according to Scobell, "just wars are good wars, and unjust wars are bad ones," ${ }^{50}$ the basic question about the real justification of war is still not answered.

\subsection{The Role of Just War}

Generally, there is huge interest in works about military history, military thought, or warfare in China ${ }^{51}$; nevertheless, examinations of the meaning of Just War are seldom. Why does the question of义战 (yi zhan), “just war or righteous war," not receive much consideration in China? The first answer would be: 春秋无义战 (chunqiu wu yizhan)52. This quote by Mengzi and the many books about the Chinese tradition in warfare show that the examinations of Just War in China seldom investigate the notion of war; rather, they look at the relation between justice and war. Although there are articles which discuss the different perspectives of Chinese philosophers regarding the notion of war or analyze the relationship between morality, virtue, and war, ${ }^{53}$ these articles do not help to comprehensively explain the phenome-

49 See Orend: Morality of War. Walzer: Just and Unjust Wars.

50 Scobell: The Chinese Cult of Defense, p. 121.

51 For an examination of Sunzi's and Mozi's military thought see 于泽民 (Yu Zemin): 两千年军事思想的沟通. 中 国古典战略今用 (The Understanding of 2000 Years Chinese Military Thought. The Present Usage of Classical Chinese Strategy), Beijing 2006. Further, a collection of historical works and comments周振甫 (Zhou Zhenfu): 古代战纪 选 (A Selection of Classical War Records), Nanjing 2005.

52 Chin. 春秋无义战 (Chunqiu wu yizhan) means: “During the Spring and Autumn Period there were no just wars". See 孟子 (Mengzi), in: 陈成国 (Chen Chengguo): 四书五经 (Four Books and Five Classics) (Vol. 1), Hunan Changshao 2002, p. 132.

53 See for instance 时殷弘 (Shi Yinhong): 关于战争与和平的伦理传统: 西方与中国 (Theoretical Tradition of War and Peace. China and the West), in: 世界经济与政治 (World Economics and Politics), No. 10 (1999). For a collection of Confucian statements about war, see 倪乐雄 (Ni Lexiong): 孔子与战争 (Confucius and War), in: 军事历 史研究 (Military Historical Record), No. 4 (1999), pp. 93-104. In view of the origin of international law and sov- 
non of Just War in China. In particular, the question of the justification of and the rules for the justification of war are not mentioned. ${ }^{54}$

From a Confucian perspective, war-if waged by the emperor-is justified per se. Therefore, if Chinese academics analyze Just War, they often describe the European understanding of Just War. Wu Zhengyu, for instance, traces the origin and development of the European Just War tradition. He also emphasizes the current significance of the Just War theory, especially with regard to international law. With a view to ethics in warfare, Zuo Gaoshan introduces the meaning of jus ad bellum and jus in bello. In this context, Zuo Gaoshan also discusses the justification of defensive warfare, particularly the question of whether the Iraq War can be regarded as defensive warfare. Furthermore, he introduces the dimension of jus post bellum and considers the different responsibilities which arise after the termination of war. ${ }^{55}$

Contrary to the former authors, Zhang Lu deals with the Chinese understanding of Just War. After a brief overview of the European tradition of Just War, his analysis aims to introduce the Chinese tradition of Just War. In Zhang Lu's opinion, the different views on war are dependent on the different evaluations of human nature in Chinese philosophy, ${ }^{56}$ although he does not sufficiently prove this hypothesis. Zhang summarizes five basic assumptions from the Chinese academic debate about Just War in China: (1) There are just and unjust wars. (2) The people's consent is the most important criteria for the justification of war. (At this point, two aspects of Zhang Lu's standpoint are difficult to understand: the emphasis on the people's consent on the one hand and the emphasis that the people's consent is the most important

ereignty during the Spring and Autumn Period as well as the Warring States Period, a discussion regarding Mozi's ideas by 桑东辉 (Sang Donghui): 也谈春秋战国时期的诸侯国是否为主权国家. 以《墨子》为例, 以国际 法为视角 (From the perspective of international law using Mozi as an example: The renewed discussion about whether the Feudal States of the Chunqiu and Warring States Period represent Sovereign States or not), in: 国际政治研究 (Studies of International Politics), No. 2 (2006), pp. 137-149. For the numerous articles about the meaning of Sunzi for politics in current-day China, see for instance 姚有志 (Yao Youzhi)/马德宝 (Ma Debao): 《孙子兵法》与当代中国主流战争理论 (Sun Zi's Art of War and Mainstream Contemporary Chinese Theories of War), in: 中国军事科学 (China Military Science), No. 6 (2004), pp. 9-16.

54 See 王联斌 (Wang Lianbin): 中华武德文化研究论纲 (Theory Outline of the Chinese Military Virtue Culture Research), in: 军事历史研究 (Military Historical Record) No. 4 (2005), pp. 150-159. 宫玉振 (Gong Yuzheng): 文化 流变与中国传统兵家的形态更替 (Cultural Transformation and the Substitution of the Chinese Traditional Military Theory), in: 军事历史研究 (Military Historical Record), No. 1 (2000), pp. 172-180. Gong presents the different schools of Chinese philosophy. He discusses the concept of Just War, especially in relation to Confucianism, and emphasizes the connection between the military strategist Wuzi and the ideas of Confucianism.

55 See左高山 (Zuo Gaoshan): 正义的战争与战争的正义. 关于战争伦理的反思 (Just War and Justice of War. About the recollection of war morality), in: 伦理学研究 (Studies in Ethics), No. 6 (2005), pp. 43-48 and 吴征宇 (Wu Zhengyu): 正义战争理论的当代意义论析 (Contemporary Meaning of the Just War Theory), in: 现代国际关系 (Contemporary International Relations), No.8 (2004), pp. 12-17.

In this context the article of Zhu Zhijiang should be mentioned, because following different perspective son realism, militarism, pacifism, and the Just War theory he generates a relation between morality and war. See 朱之江 (Zhu Zhijiang): 论道德视角下的战争 (Discussion of war from a moral viewpoint), in: 军事历史研究 (Military Historical Research), Nr. 1 (2005), S.142-152.

56 See 张露 (Zhang Lu): 中西正义战争思想比较分析 (A Comparison of Chinese and Western Just War Thought), in: 现代国际关系 (Contemporary International Relations), No. 4 (2005), pp. 15-20. Following Zhang, there are philosophers who characterize human nature as good or bad, others who claim that the origin lies within human nature, and again others who maintain an ambiguous attitude towards human nature. The relation between human nature and the idea of Just War is, however, controversial. Author's interview with Professor Yang Lihua, Beijing University, October 2006. 
criteria for the justification of war on the other hand. He does not clarify the correlation between both aspects.) (3) War that supports justice. (4) The caution of waging war and the condemnation of aggressive warfare. (5) The ultimate goal of war is not only the punishment of war crimes, but also the establishment of universal morality and justice. ${ }^{57}$ Zhang Lu further compares the European and the Chinese traditions of Just War. He intends to show that the European criteria for Just War were already famous within the classic Chinese philosophy. The main difference consists of the Chinese opposition to the idea of hegemony and power politics. ${ }^{58}$ Finally, Zhang Lu emphasizes the peaceful orientation of the Chinese tradition, but he still does not introduce rules or criteria for a Chinese meaning of Just War.

In contrast to their Chinese colleagues, two representatives of the Western debate, Mark E. Lewis and Karen Turner, primarily emphasize the common ground between the European and Chinese traditions of Just War. ${ }^{59}$ In his examination of Just War in China, Mark E. Lewis refers to the early writings in Chinese philosophy, particularly works from the Qin and Han dynasties (221 B.C. and 220 A.C.). In the context of the Spring and Autumn as well as the Warring States periods, Lewis mostly examines Confucian writings, especially Mencius and Xun $\mathrm{Zi}$, and military classics such as Sun $\mathrm{Zi}, \mathrm{Wu} \mathrm{Zi}$, and the Simafa. ${ }^{60}$ Mark Lewis' article is a brief but helpful introduction to the Chinese understanding of war and justice.

\section{The Chinese Tradition of Just War: Confucianism and Military Strategists}

The Spring and Autumn Period, as well as the Warring States Period, represent the origin of Chinese philosophy since the most important schools of thought were founded during this period. The cruelty and the social unrest in most of the kingdoms at that time resulted in a high level of creativity. ${ }^{61}$ The careful examination of these classics is, therefore, the foundation for the discussion of the Chinese concept of Just War. ${ }^{62}$ Following Alastair Johnston and Andrew Scobell, this article focuses on the Confucian viewpoint and the writings of the military strategists.

57 See 张露 (Zhang Lu): 中西正义战争思想比较分析 (A Comparison of Chinese and Western Just War Thought), p. 18.

58 See 张露 (Zhang Lu): 中西正义战争思想比较分析 (A Comparison of Chinese and Western Just War Thought), p. 20.

59 See Lewis, Mark E: The Just War in Early China, in: Torkel, Brekke (ed.): The Ethics of War in Asian Civilizations, pp. 185-200 and Turner, Karen: War, Punishment and The Law of nature in Early Chinese Concepts of the State, in: Harvard Journal of Asiatic Studies, Vol. 53, No. 2 (1993), pp. 285-324, esp. about Just War in China pp. 296-305.

60 See Lewis: The Just War in Early China, pp. 185-189. In contrast to Thomas Kane, Lewis does not analyze the role of Daoism. See Kane, Thomas M.: Inauspicious Tools: Chinese Thought on the Morality of Warfare, in: Robinson, Paul (ed.): Just War in Comparative Perspective, Ashgate 2003, pp. 139-152, esp. p. 141- 147. Concerning the discussion of Just War, the examination of Taoism is difficult, because Taoist thought denies the existence of government or in a broader sense the state. Professor Xing Taotao and Professor Cheng Lian from Beijing University support this standpoint. Interview with the author in September 2006.

61 Creel, Herlee G.: The Origins of Statecraft in China (Vol. 1). The Western Chou Empire, Taipei 1970, p. 42: "It would probably be generally agreed that for most practical purposes the Chinese tradition may be said to have begun with the Chou."

62 The Chinese classics are considered to consist of the Confucian writings, the Maoist and Legalist writings, and the military classics written during the Warring States Period. In this article I will focus on the Confucians' and military strategists' perspectives. 


\subsection{Confucianism}

The different Confucian writings mainly deal with questions regarding the structure of the political order and the establishment of the emperor's authority-in other words, with the question of how a country shall be ruled. The pivotal focus of this examination is the internal organization of the political system. If the emperor holds the Mandate of Heaven (tianming), ${ }^{63}$ then his authority will extend to every man living under heaven (tianxia). ${ }^{64}$ Consequently, the emperor is called the Son of Heaven $(\text { tianzi })^{65}$. The claim to power is not regionally limited because the emperor is appointed by heaven (tian) and thus comparable to the highest divinity ${ }^{66}$. Herein lies the reason why Confucians mainly stress the internal organization of state. The external perspective is not part of their idea of authority. An emperor who establishes a Confucian order will ideally rule all under heaven (tianxia) ${ }^{67}$

It follows that from a Chinese perspective domestic and foreign policy are not separated; therefore, internal (civil) and external wars are also not distinguished from one another. Moreover, internal and external wars coincide with this understanding of authority. The union of internal and external politics (or wars) is the central phenomenon within Confucian writings. Nevertheless, this perception of authority, which establishes an empire without boundaries, can be identified in various cultures. It is not a unique Chinese phenomenon but rather a universal one. ${ }^{6} 8$

For the identification of Just War criteria it must be recognized that there is no difference between the emperor's behavior within a state and towards other states. From a Confucian perspective, power and authority are not enforced by violence; rather, Confucian authority is based on a moral perception of power. A moral and supreme emperor seizes power without the use of force. So with regard to foreign affairs and the question of war, the Confucian emperor is victorious without fighting. It is, therefore, important to recognize the fundamental correlation between internal and external affairs while analyzing the Confucian writings about questions of (Just) War.

Although the Confucians, especially Mengzi, emphasize that wars of conquest and wars for profit are condemned, it seems that there is a difference between war and "punishment." For

Chin. 天命 (tianming).

64 Chin. 天下 (tianxia).

65 Chin. 天子 (tianzi).

66 For a broader understanding of heaven in Chinese philosophy see Zhang, Dainian: Key Concepts in Chinese Philosophy (transl. and ed. by Edmund Ryden), New Haven/London 2002, pp. 3-11.

67 For a good summary of the notion of Tianxia, see Qin Yaoqing: Why there is no Chinese International Relations Theory?, in: International Relations of the Asia-Pacific, Vol. 7 No. 3 (2007), pp. 313-340.

68 See for instance the scientific debate about the Imperium Romanum or "Imperium sine fine" (Engl. "Empire without boundaries") Lintott, Andrew: Imperium Romanum. Politics and administration, London/New York 1993, p. 1: "According to Cicero, [...] it was asserted that the land in which Scipio lived was bound to rule the earth." It is important to realize that this phenomenon is not specifically Chinese, but rather universal. Despite Rome it is also found in Traditional Persia. See Briant, Pierre: Histoire de l'empire Perse. De Cyrus à Alexander, Paris 1996; Münkler, Herfried: Imperien: die Logik der Weltherrschaft - vom Alten Rom bis zu den Vereinigten Staaten, Hamburg 2007. 
this reason, a "punitive expedition" 69 is valued differently from general warfare and represents the type of war which is morally justified. A punitive war is different because the reason for war lies in the moral decline of the political order. This means that an attack can be justified when the harmony between the emperor and his people is disturbed. Annexation by another kingdom or rebellion against an immoral and unjust emperor is legitimized because it is viewed as the emperor's righteous punishment.

Confucius highlights the moral decline within a political community as a just reason to wage a war. Once Confucius told the emperor of Lu that the emperor of Qi was murdered by a senior official who wanted to gain power in the Kingdom of Qi. Confucius gave the advice that this immoral offence needed to be punished to restore the internal order of Qi. From Confucius' viewpoint, a "punitive expedition" - or in other words, a war - against Qi was justified. ${ }^{70}$

According to Confucius, a crime which potentially affects the political system of another kingdom is a legitimate reason to send a "punitive expedition." This argument alludes to two things: Firstly, there is the tremendous role of domestic politics in connection with the justification of war. This means a moral offence or a violation of Confucian traditions could legitimize an attack by another state. Secondly, war is possible, even likely, without a previous act of aggression. These understandings of "war" or as the Confucians say "punishments" lead to some difficulties. If a State $X$ is ruled by Confucian measures and another State $\mathrm{Y}$ is not, then the Confucians discuss the possibility of State $\mathrm{X}$ sending a punitive expedition to State Y. Although this particular "punishment" is considered to be different from a conventional war, it still implies the use of force. In other words, the Confucians legitimize punitive warfare because of a "potential danger." In this context the idea of punishment extends beyond the understanding of war. Hence, the internal collapse of one state is automatically understood as a threat to another state. When a state tries to smooth this danger out, it means sending a "punitive expedition." So the case of "punitive expeditions" appears to be similar to the idea of prevention; however, punishment is fundamentally contrary to prevention. Its essence lies in the fact that the implementation of the penalty follows the crime. The different interpretations of "punitive expedition" as, for instance, annexation, rebellion, defense, or prevention, disguise the actual understanding of war which is justified by the Confucians. Most reviews and analyses of the Chinese concept of Just War use "punitive expedition" as the common translation of the Confucian term for a justified war. Even though this translation is literally correct, it seems inappropriate in regard to the context. The internal organization of the political order is the main subject in Confucianism, even with regard to the justification of war. Thus, it makes sense to use the expression "war of order" instead of "punitive expedition".

The Confucian idea of political order is based on humanity (ren), righteousness (yi), and traditional conventions $(l i)$. The emperor's absolute authority is the reason for the insignificance of war. If the use of force is not necessary, then why are armed forces nevertheless a part of

Chin. 诛伐 (zhufa).

70 See Confucius: Analects of Confucius, Beijing 1994, XIV, 21. 
the Confucian political order? ${ }^{71}$ This contradiction between the ideal of a Confucian political order and the possibility of war at the same time is difficult for the Confucians to explain. It is important to recognize that war plays a decisive role in Confucianism. Despite the emphasis on peaceful preferences, Confucius also highlights the military's position:

Zi-Gong asked what was needed for government. Confucius said, "Sufficient food, sufficient armaments, and common people's trust in government." Zi-Gong asked, "Suppose you were forced to get rid of one of the three, which one would you get rid of first?" Confucius said, "Armaments." 72

Even though the military is the first need which is dispensable, it is still part of the righteous government. It follows that the use of force is not excluded a priori. Although war is not a classic Confucian topic, there still exist criteria which obviously justify a "war of order."

\subsection{Military Strategists}

The most influential writings about Chinese military thought were written during the Warring States Period, in which war and cruelty occurred frequently. With some exceptions, the vast majority of the military classics were also created in this period..$^{73}$ These military classics deal with the state's organization and administration. Similar to the works of the Confucians, these classics focus on the emperor's position and ideal leadership as their starting point. With the exception of Sunzi, all military strategists firstly discussed the internal organization of political order and then emphasized the necessity of armed forces to guarantee stability and security within the state. The authors chiefly stressed the analysis of tactics which could be used during a war, for instance, the means of the emperor and the position of his army or his general. A fundamental goal of the military strategists was to limit the use of force. War is still condemned in these writings, but it is argued that Just Wars need to be waged. Military strategies were, therefore, necessary, especially when victory should be realized with a minimum of costs.

When referring to the question of Just War, the military strategists need to be considered for two reasons. Although it seems that the legitimacy of military actions is not a central subject of their writings, the military strategists developed certain conditions which justified the use of their strategies. Firstly, it had to be a Just War. Secondly, they underlined what means of war should generally be used and how these means should be judged. Thus, the military strategists - in contrast to the European tradition of Just War-also considered the independence of

71 Hsün-tzu (transl. by Hermann Köster), Kaldenkirchen 1967.

72 Confucius: Analects, XII, 7.

73 The exceptions are 黃石共三略 (Huang Shi Gong San lue), which was written in Han dynasty (206-220 B.C.) and the 唐太宋問對李衛公 (Tang Taisong wen dui Li Weigong), written during the Tang dynasty (618-907 A. D.). Another work The secret Teachings of Tai Gong was created in the eleventh century, though Sawyer's translation is based on a transcript from the Warring States Period. See Sawyer, Raph D.: The Seven Military Classics of Ancient China (transl. by Ralph D. Sawyer with Mei-chün Sawyer), Boulder/San Francisco/Oxford 1993. p. 23. At the beginning of the 1970s the transcript of Sun Bin's Military Methods was rediscovered. See Sun Pin: Military Methods (transl. by Ralph D. Sawyer with Mei-chün Sawyer), Boulder/San Francisco/Oxford 1995. 
the justification of war (jus ad bellum) from the means of war (jus in bello) in particular. The proportionality of means was further examined in the context of stratagem and deception.

In contrast to the Confucian writings, the relation between wen and $w u^{74}-$ more precisely, the role of the military within the social order-is the most important topic of the military classics. According to the methods of Sima, the basis of authority is not only a harmonious society, but also warfare: "Authority comes from warfare, not from harmony among men."75 Although the internal order still consists of harmony, the external position of a kingdom can only be secured with the help of warfare. "Within, [the government] gains the love of the people, the means by which it can be preserved. Outside, it acquires awesomeness, the means by which it can wage war." Nevertheless, war may not be waged arbitrarily, because this would cause the decline of authority. "Thus, even though a state may be vast, those who love warfare will inevitably perish. Even though calm may prevail under Heaven, those who forget warfare will certainly be endangered!" Sunzi also mentions that war is a social phenomenon but possesses destructive powers at the same time. "Warfare is the greatest affair of state, the basis of life and death, the Way [Tao] to survival or extinction. It must be thoroughly pondered and analyzed." ${ }^{\prime 76}$ As a result, the reasons for war are of particular significance.

Wuzi, for instance, specifies five general reasons for war: to protect the emperor's reputation, to gain benefits, hatred, civil unrest, and war as a result of famine. Moreover, Wuzi points out five types of war: Just Wars which save mankind from chaos; aggressions which are exercised with the acceptance of the people; wars which mobilize the army out of rage; wars which are waged only for profit; and "contrary wars" which are fought even when the people are in a state of emergency or weakened because of famine. ${ }^{77}$

The concept of Just War was not only a political instrument for the military strategists but also the foundation for the development of their strategies. The general criteria for Just War mentioned by the different military strategists are as follows: the emperor's authority, which finally decides on the use of force; war as defensive warfare and therefore as a direct reaction to an aggressive attack by another state; and the use of force as a last resort. In addition, war has to be useful for the people, because the people guarantee the emperor's power. ${ }^{78}$ Yet another aspect expressed by the military strategists is that war should only be fought when victory is certain. The aim of war is victory or -in a broader sense-peace.

74 Chin. 文 (wen) means civil; Chin. 武 (wu) means military. These characters describe the two sides of the dilemma. The role of armed forces within the social (or civil) order was the most important topic for the military strategists. See about wen and wu Fairbank: Introduction, p. $2 \mathrm{f}$.

75 See here and in the following Sawyer: The Seven Military Classics of Ancient China, Chapter 2: The Methods of Ssu-ma, p. 126.

76 Sawyer: The Seven Military Classics of Ancient China, p. 157.

77 See Sawyer: The Seven Military Classics of Ancient China, p. 208 und Johnston: Cultural Realism., p. 67.

78 The important role of the people is mentioned in various writings. See Sawyer: Seven Military Classics of Ancient China, Introduction, p. 32. See also in the Methods of the Sima, Sawyer: Seven Military Classics of Ancient China, p. 126: "Authority comes from warfare, not from harmony among men. For this reason if one must kill men to give peace to the people, then killing is permissible. If one must attack a state out of love for their people, then attacking is permissible." 


\subsection{The Ambiguous Meaning of Defensive Warfare}

Defense is a legitimate reason to raise a war, but defense is not consistently understood as a reaction to previous aggression. From a Confucian perspective, the meaning of defense allows further interpretations. On the one hand, defense represents a criterion for Just War, but on the other hand, the criteria for defense itself are not examined. The various means of war recognized by the military strategists clearly underline this assumption. It therefore seems that defense is significantly more than just a reaction to previous aggression. Defense according to the military strategists prevents direct confrontations; it makes victory possible before war actually breaks out. At first glance this appears to be a contradiction, but it actually describes the core of Chinese military thought. Winning without fighting requires that defensive measures are undertaken before the enemy's first strike. Following this interpretation, defense also implies direct action. ${ }^{79}$

Thus, the true art of war is to defeat the enemy without fighting. As Sunzi states, "For to win one hundred victories in one hundred battles is not the acme of skill. To subdue the enemy without fighting is the acme of skill." 80 But even Just War still means war, although it should be reduced to a minimum. This is the reason why warfare begins before the first gunshot. Preventive measures are used to avoid actual combat. Referring to the Chinese concept of Just War, this would definitely extend the meaning of defense as a righteous cause of war. Sunzi further mentions, "Thus, what is of supreme importance in war is to attack the enemy's strategy. Next best is to disrupt his alliances. The next best is to attack his army. The worst policy is to attack cities. Attack cities only when there is no alternative." 81

Sunzi does not clarify what "to attack the enemy's strategy" or "to disrupt its alliances" exactly means. One interpretation could be that Sunzi supports mainly diplomatic solutions, but in the context of other statements from the Art of War a more offensive reading is possible. The various Sunzi commentators point out that "to attack the strategy" can also mean to destroy the enemy's material resources. ${ }^{82}$ In addition, the enemy should be attacked while he is still planning the aggression; in other words, the potential threat should be nipped in the bud. Consequently, this preventive idea seems necessary to ensure that force is actually used as a last resort. With regard to the matter of defense, the potential threat of an aggressive strategy is reason enough to "actively defend" oneself. Knowledge about the enemy's situation, army, and potential behavior is, therefore, of particular importance in order to gain victory. For this reason, espionage constitutes a significant part of warfare, because strategies cannot be attacked without information about the adversary's intentions. Sunzi also mentions the role of "foreknowledge." "What is called 'foreknowledge' cannot be elicited from spirits, nor from gods, nor by analogy with past events, nor from calculations. It must be obtained from

79 According to Andrew Scobell, the "ambiguous understanding of defence" describes the basic perception of strategic culture in China. See Scobell: China's Use of Military Force, p. 26.

80 Sun Tzu: The Art of War (transl. by. Samuel B. Griffith), Oxford 1963, III, 3.

81 Sun Tzu: The Art of War, III, 4-7.

82 For more on Sunzi's commentators see Sun Tsu: Wahrhaft siegt, wer nicht kämpft (transl. by Ingrid FischerSchreiber), Freiburg 1990, pp. 50-54; p. 93 f. 
men who know the enemy situation." 83 Secret agents or the secret service in general are central means of war, especially when the enemy is to be beaten with minimum costs.

Another aspect which is highlighted by the military strategists is the use of stratagems or deception during acts of war. The military strategists stress the role of stratagems as being deceptions which disguise the true strategies of action. In the context of the understanding of espionage, it seems that deception plays a more essential role. Although there are criteria for fighting a Just War, the impression that almost every means seems justified to win a war is evident. Sunzi further identifies deception as the fundamental basis of warfare. ${ }^{84}$ The meaning of deception, therefore, includes not only the concealment of information; deception also describes an active measure of war and the starting point for the development of war strategy. Burles and Shulsky also underline that it is more about forcing the enemy to act the way you want him to act, so that the enemy's behavior serves to your own advantage. ${ }^{85}$

Orthodox and unorthodox tactics during war are measures to simply control the enemy. For the military strategists Sunzi, Sun Bin, and Tai Gong, unorthodox means of war describe a central measure for gaining victory. As Sunzi says, "Generally, in battle, use the normal [orthodox, N.G.] force to engage; use the extraordinary [unorthodox, N.G.] to win." 86 Sawyer explains that orthodox tactics imply textbook confrontations, for instance, fighting at the front. Unorthodox tactics, on the other hand, illustrate a flexible and surprising use of armed forces. Sawyer concludes,

Thus, $[\ldots]$, the orthodox may be used in unorthodox ways, and an orthodox attack may be unorthodox when it is unexpected precisely because it is orthodox-whereas a flanking or indirect assault would be thereby be considered normal therefore orthodox. ${ }^{87}$

The surprise effect of flexible warfare is a decisive guarantee of victory. Hence, the pragmatic counterpart of deception as a strategic basis of warfare lies in the use of unorthodox tactics. Neither deception nor unorthodox measures are condemned; these means of war are justified by the military strategists.

83 Sun Tzu: The Art of War, XIII, 3-4.

84 Sun Tzu: The Art of War, I, 17 and I; 18-27: “Therefore, when capable, feign incapacity; when active, inactivity. When near, make it appear that you are far away; when far away, that you are near. Offer the enemy a bait to lure him; feign disorder and strike him. [...] Attack where he is unprepared; sally out when he does not expect you. These are the strategist's keys to victory. It is not possible to discuss them beforehand."

85 See Burles, Mark/Abram N. SHULSKY: Patterns in China's Use of Force. Evidence from History and Doctrinal Writings, Washington 2000, Appendix, pp. 79-95, esp. p. 89.

86 Sun Tzu: The Art of War, V, 5.

87 Sawye: The Seven Military Classics of Ancient China, Notes to Sun-tzu's Art of War, Fn. 33, p. 427. See also: Sun Pin: Military Methods (transl. by. Ralph D. Sawyer with Mei-chün Sawyer), Boulder/San Francisco/Oxford 1995, p. 233. 


\section{General Characteristics of Just War in the Chinese Tradition ${ }^{88}$}

After analyzing the different Chinese philosophical perceptions, it becomes unambiguous that even in China's traditional thinking, war and violence can be justified. Confucius actually introduces the possibility of a "punitive expedition," although the criteria for a preventive intervention remain questionable. The classic Confucian writings mainly deal with the maintenance and organization of political order; it is, therefore, necessary to determine the Chinese meaning of Just War from the description of political community in traditional China.

In accordance with an era of relative political stability during the Western Zhou dynasty (1122-771 B.C.), ${ }^{89}$ the (ideal) Confucian emperor represents the unity of harmony and stability. He is the core of the traditional Chinese political order and his virtue serves as an example for the "common man" (xiao ren). On the other hand, the people are indebted to the emperor's authority. Consequently, the hierarchical order determines the relationship between the emperor and the people. He surely rules for the people, but is not legitimated by the people; the hierarchical relations are characterized by mutual responsibilities, not by rights and duties. The emperor holds the Mandate of Heaven (tianming) and because of his moral authority gains power without fighting. The domestic harmony which is highlighted in the Confucian understanding of peace also influences the perception of the empire's external stability. "The Chinese world order, therefore, was as much an ethical as a political phenomenon. Harmony internationally as well as domestically was the product of the emperor's virtue." ${ }^{\prime 90}$ Ideally, no other political community could or would elude the harmony of the Chinese emperor.

The claim to authority was regionally unlimited, because harmony did not know boundaries. Outside of China there was no other reliable political self-organization, and China's neighbors in the periphery were described as barbarians or vassal states.

The Chinese tended to think of their foreign relations as giving expression externally to the same principles of social and political order that were manifested internally within the Chinese state and society. [...] China's external order was so closely related to her internal order that one could not long survive without the other; when the barbarians were not submissive abroad, rebels might more easily arise within. Most dynasties collapsed under the twin blows of "inside disorder and outside calamity." 11

Because of the boundless claim to authority, the Chinese tradition lacks a distinction between international and domestic conflicts; both are primarily considered as disturbances of harmony. Peace is, therefore, the absence of disturbance-in other words synonymous with

88 For his comments and suggestions on the following two sections, I would like to thank Dr. Oliver Lembcke. Many aspects were also presented together at the DVPW-Arbeitskreis "Politik und Religion", 27-29 June 2008 in Berlin.

89 "Die Zhou Dynastie folgt den beiden vorangegangenen Dynastien der Xia und Shang. Wie vornehm und kultiviert! Ich folge Zhou."(The Zhou Dynasty refers to the previous dynasties of the Xia and Shang. How distinguished and civilized! I follow Zhou.) Konfuzius (1982): Gespräche (transl. by Ralf Moritz), Leipzig, III, 14.

90 Zhao, Suisheng: Power Competition in East Asia: from the old Chinese world order to post-cold war regional multipolarity, London 1997, p. 8.

91 Fairbank, John K. (ed.) (1968): The Chinese World Order. Traditional China's foreign relations, Cambridge, p. 3. 
harmony, which is represented by the emperor. Peace, however, is not a political concept; ${ }^{92}$ it cannot be actively founded by the emperor. But if the harmony is challenged, the emperor has the duty to restore political order, an act which can also include the use of violence.

Consequently, the traditional focus on the maintenance of political order is central to the Chinese understanding of Just War, because continuous disorder is considered more dangerous than the use of military violence. "The internal disintegration of a nation is more dangerous than its external aggression [...]. Furthermore, internal disintegration is likely to invite aggression from without and in that case the State is defenceless for there is no unity within." 93 It follows that violence and war are justified when the emperor intends to eliminate the disorder. In this context, the justified war is referred to as a "punitive expedition." Furthermore, the aggression of another political community must not precede the actual use of violence, because it is the maintenance of political order which can lead to a military intervention, even when it is the domestic decline of political order in a neighboring state that entails a potential threat. Moreover, a military intervention can be raised with the intention to contain the potential danger of anarchy. In these cases of preventive intervention it makes sense to use the expression "war of order" instead of "punitive expedition"; the rules for such an intervention still remain uncertain.

The means of war also highlight the traditional Chinese attitude towards the use of violence, especially the ambiguous understanding of defense. Defensive warfare not only implies a reaction to previous aggression, but also denotes an active military strike. According to the military strategists and the Confucians, the meaning of war is to achieve victory without fighting; defensive warfare begins even before the first movement of the enemy. This understanding of defense implies that a potential threat can be solved preemptively and highlights the possible use of preventive violence. A central aim is to control the enemy's actions before a potential threat becomes a real one. ${ }^{94}$ In this context, defeating the enemy without fighting implies that the use of military violence should be restricted to an absolute minimum. These means do not exclude violence, but they should still avoid bellicose actions: (1) On the one hand, deception describes the withdrawal of information, the concealment of tactics, or an ambush. On the other hand, the Chinese understanding of deception extends beyond this general understanding. Deception is further viewed as the basis of warfare. This includes, for instance, the active control of the enemy's resources or influencing the enemy's actions in a way that serves one's own goals. The Chinese idea of deception or stratagems is not kept secret, because deception or stratagems are not interpreted negatively but rather as a sign of intelligence. (2) The orthodox and unorthodox methods are closely linked to the meaning of deception. It is essential that unorthodox tactics such as deploying troops flexibly and sur-

92 As it was, for instance, developed by Thomas Hobbes, see Hobbes, Thomas: Leviathan: Oder Stoff, Form und Gewalt eines kirchlichen und bürgerlichen Staates (edited by Irene Fetscher), Frankfurt am Main 2006 [1651].

93 Hsü, Leonard S.: The Political Philosophy of Confucianism. An Interpretation of the Social and Political Ideas of Confucius, his Forerunners, and his early Disciples, London/Dublin/New York 1932, p. 73.

94 On the one hand this aspect is difficult to combine with the Just War theory, but on the other hand it points out a current debate: whether-or when-a preventive or preemptive strike could be justified. 
prisingly if it ensures victory and success are justified. Hence, war waged by the emperor seems to be more similar to a police action than a military one. Defense can be understood as preventive and also includes direct action with the help of unorthodox methods. War, justice, and prevention stand closely together in Chinese tradition. Thus, the term "war of order" gets closer to the core of the Chinese understanding of a Just War and does not conceal the possibility of preventive intervention.

\section{Just War in a Harmonious World: Implications of a Traditional Concept for Con- temporary Chinese Foreign Policy}

Uncertainties about China's true foreign policy orientation still dominate the academic debate; even the representatives of different approaches in international relations theory cannot find a clear answer. Consequently, the numerous analyses about the impact of China's ascent on the (East) Asian regional order or on US-China relations range between peaceful or bellicose perceptions of China's future engagement in the region and in the world.

Aaron L. Friedberg shows that this uncertainty about China's future path is one of the most controversial issues in the academic debate. ${ }^{95}$ "It is possible to identify liberals who expect confrontation and conflict, realists who believe that the relationship will basically be stable and peaceful, and constructivists who think that events could go either way." ${ }^{\prime 96}$ Friedberg aims to categorize the liberal, realist, as well as constructivist approaches around either an optimistic or pessimistic perception of Chinese foreign policy. ${ }^{97}$ For liberal optimists, the growing economic interdependence between China and the United States has strengthened the mutual interest in peace between the two countries and in the Asia-Pacific region. Further, the embeddedness of China in international institutions such as the WTO and regional institutions such as the ARF, ASEAN+3 or the East Asian Summit will promote "contact, communication and, over time, greater mutual understanding and even trust." ${ }^{98}$ Both aspects, interdependence and institutions, would also promote the process of democratization in China. On the contrary, realists' attitudes are mostly pessimistic. In this context, Friedberg particularly emphasizes China's incredible economic and military ascent, which is threatening not only because of its speed, but also because of "its growing mass and enormous potential." ${ }^{99} \mathrm{He}$ sub-

95 Friedberg, Aaron: The Future of U.S.-China relations. Is Conflict inevitable?, in: International Security, Vol. 30 No. 2 (2005, pp. 7-45.

96 Friedberg, p. 10.

${ }_{97}$ A similar attempt was made by Thomas J. Christensen, but he only distinguishes between a positive-sum perspective "in which the United States, China, and other regional actors have strong incentives to increase mutual trust, transparency, and economic ties, thereby minimizing the likelihood of avoidable military conflicts that serve no nation's long-term interests" and a zero-sum perspective "in which the continued relative increase in Chinese power poses the most formidable long-term danger to the national security and economic interest of the United States and its allies in the region [...]." Christensen, Thomas J.: Fostering Stability or Creating a Monster? The Rise of China and U.S. policy toward East Asia, in: International Security, Vol. 31, No. 1 (2006), p. 81.

98 Friedberg, p. 14.

$99 \quad$ Friedberg, p. 17. 
sequently argues that rising powers aim to expand their power and, consequently, challenge the established powers. In the tradition of offensive theorists, a confrontation between rising and established powers is seldom resolved peacefully. From this perspective, China's predominant goal would be to push the United States out of their sphere of influence in East Asia. Realist optimists, however, argue that even though the balance of power between the US and China needs to be monitored, China's power capabilities are weaker in reality than many analysts have claimed. While China's economy and military power is growing, the power of the United States has not stopped growing. ${ }^{100}$ According to the realist optimists, a rising power does not necessarily act aggressively. Rising powers can have different political intentions and their aims can be limited. ${ }^{101}$ Therefore, realist optimists describe the dominant security dilemma as muted. The liberal pessimists question the structure of the Chinese political system and its potential for democratization. The PRC is still an authoritarian state. Furthermore, the Chinese government supports the growth of a strong nationalist sentiment towards Taiwan, Japan, and the United States. Even if China's political system were to transform into a more democratic one, the impact on US-China relations would not automatically be a given. And "if China does not change [...] certain persistent features of America's domestic regime appear likely to incline the United States toward conflict with the PRC."102 This would turn the democratic peace argument around. Liberal pessimists worry that this situation would lead to a "vicious cycle of mutually reinforcing suspicions and fears."103

Constructivist optimists argue that people can change the environment by following their beliefs and ideas. Even though China's traditional thinking is determined by the "parabellum paradigm,"104 the constructivist optimists claim that Chinese politicians can change their attitude via increasing international embeddedness and institutional contact. Constructivist pessimists, however, maintain that concerning China, "positive change is likely to be a long time in coming." 105 Therefore, the interaction with the outside world could also harden relations with the US or China's political intentions because of the experience of shocks and crises.

Friedberg's attempt to categorize the dominant patterns of the theoretical debate gives a good impression of the difficulty of determining China's future foreign policy intentions. He tries to synthesize the six different positions and further emphasizes that "each of the six positions captures some aspect of reality and that most, and perhaps all, of the causal mechanisms that they describe are at work simultaneously." 106 But the question which Friedberg

100 See for instance Segal, Gerald: Does China Matter?, in: Foreign Affairs, Vol. 78, No. 5 (1999), pp. 24-36; AlRhodan, Khalid R.: A Critique of the China Threat Theory: A Systematic Analysis, in: Asian Perspective, Vol. 31, No. 3 (2007), pp. 41-66.

101 For the Chinese case, see David Shambaugh, who states that “China's regional power and influence need not result in a reciprocal decrease in U.S. power and influence. Acquiring and wielding power and influence in a non-bipolar system [...] is not a zero-sum game." Shambaugh, David: China engages Asia. Reshaping the Regional Order, in: International Security, Vol. 29 No.3 (2003/2004), pp. 64-99.

102 Friedberg, p. 31.

103 Friedberg, p. 33.

104 Johnston: Cultural Realism.

105 Friedberg, p. 37.

106 Friedberg, p. 39. 
also cannot answer is whether the PRC itself has an idea of its future foreign policy orientation. The general uncertainty can therefore be united in one question: What is China's concept of (regional and international) order? Friedberg's categorization is one step in the right direction, but his classification of the different analyses into the six positions is not always without doubt. ${ }^{107}$ It seems that the examination of the different IR theories, though important, can only shed limited light on China's future political status.

In contrast to Friedberg's focus on IR theories, Alastair Iain Johnston emphasizes the underlying cultural pattern of Chinese traditional foreign policy, which supports his "parabellum paradigm" hypothesis. Johnston, as well as Andrew Scobell, combines cultural aspects with a realist perspective on China's foreign policy behavior. This connection between Chinese traditional thinking and contemporary political attitudes is usually a strong argument among Chinese academics and is also often mentioned in official documents which highlight the peaceful and harmonious orientation of the PRC. ${ }^{108}$ But the representatives of the strategic culture debate are not the only ones who do this; authors such as David Kang also try to link the traditional Chinese ideas of political order with China's contemporary role in the region as well as in the world. ${ }^{109}$ With regard to Friedberg's classification, I provide an enhanced matrix where I combine Friedberg's result with the surveyed patterns of Just War in traditional China (see Chart 1).

It is conspicuous that the Chinese perspective is mainly determined by Chinese academics and official statements which, amongst other things, refer to the peaceful writings of Confucius. ${ }^{110}$ The benign character of Chinese politics is, therefore, found not only in official documents and statements but also in Chinese political analyses, which are keen to spread the image of a peaceful China into the academic world. This Chinese self-perception needs to be questioned through an analysis of the Chinese traditional writings. Alastair Iain Johnston, for instance, focuses on the peace-loving (Confucian) and military (military classics) orientation of the Chinese tradition, but in the end he mainly emphasizes the military tradition in China (parabellum paradigm). This, however, stands in contrast to his discussion about the contemporary political intentions of the PRC, where he argues that China today represents a status quo power. How is this change from the traditional "parabellum paradigm" to a China as a "status quo power" possible? The Chinese self-perception and others' percep-

107 One criticism could be the question of whether the representatives of the different IR theories always stand for only one of Friedberg's six positions or whether most of them do not already combine different approaches?

108 See for example, Ministry of Foreign Affairs of the People Republic of China: Peace, Development and Cooperation. In Commemoration of the 35th Anniversary of Restoration of Lawful Seat of the People's Republic of China in the United Nations, 2006, www.fmprc.gov.cn/ng/wjb/zzjg/gjs/gjsxw/t278484.htm, last accessed on 4 December 2007; Li Zhaoxing: Peace, Development and Cooperation. Banner for China's Diplomacy in the New Era, 08/2005, www.fmprc.gov.cn/eng/zxxx/t208032.htm, last accessed on 4 June 2008; 中国的和平发展道路 (China's Way of Peace and Development), www.gov.cn/zwgk/2005-12/22/content_134060.htm, last accessed on 6 June 2008; 孙学峰Sun Xuefeng): 和谐世界理念与中国国际关系理论研究 (The concept of a harmonious world and the study of Chinese international relations theory), in: 教学与研究 (Education and Research), Vol. 11, 2007.

109 Recently published by David C. Kang: China Rising. Peace, Power, and Order in East Asia, New York 2007.

110 See for an overview Billioud, Sébastian: Confucianism, “Cultural Tradition”, and Official Discourse in China at the start of the New Century, in: China Perspectives, Vol. 69, No. 3 (2007), pp. 50-65. 
tions of China, as well as the connection between Chinese culture and current Chinese polices, need to be analyzed further.

\section{Chart 1: Patterns of Chinese Foreign Policy in Modern and Traditional China}

\begin{tabular}{|c|c|c|c|c|}
\hline \multirow[t]{2}{*}{ Pattern } & \multicolumn{2}{|c|}{ Modern China } & \multicolumn{2}{|c|}{ Traditional China } \\
\hline & China & West & China & West \\
\hline $\begin{array}{l}\text { Peaceful/ } \\
\text { Cooperation }\end{array}$ & $\begin{array}{l}\text { Harmonious society/ } \\
\text { harmonious world } \\
\text { (official documents), } \\
\text { cultural moralism } \\
\text { (Tiejun Zhang) }\end{array}$ & $\begin{array}{l}\text { Liberal optimists, } \\
\text { constructivist } \\
\text { optimists }\end{array}$ & $\begin{array}{l}\text { Cultural moralism } \\
\text { (Tiejun Zhang) }\end{array}$ & $\begin{array}{l}\text { Interpretations in view of } \\
\text { Chinese classical writings } \\
\text { (John K. Fairbank, Adel- } \\
\text { mann/Shih). } \\
\text { "War was seen as aberra- } \\
\text { tion." }\end{array}$ \\
\hline $\begin{array}{l}\text { Bellicose/ } \\
\text { Conflict/ } \\
\text { Revisionist }\end{array}$ & $?$ & $\begin{array}{l}\text { Realist pessimists, } \\
\text { liberal pessimists }\end{array}$ & $?$ & $\begin{array}{l}\text { Interpretations which refer } \\
\text { to Confucianism and the } \\
\text { military strategists as de- } \\
\text { termining patterns of Chi- } \\
\text { nese traditional foreign } \\
\text { policy (Alastair Iain Johns- } \\
\text { ton, Andrew Scobell). }\end{array}$ \\
\hline $\begin{array}{l}\text { Peaceful } \\
\text { and } \\
\text { bellicose/ } \\
\text { Status quo }\end{array}$ & $?$ & $\begin{array}{l}\text { Realist optimists, } \\
\text { constructivist } \\
\text { pessimists }\end{array}$ & $?$ & $\begin{array}{l}\text { Interpretations which refer } \\
\text { to Confucianism and the } \\
\text { military strategists as de- } \\
\text { termining patterns of Chi- } \\
\text { nese traditional foreign } \\
\text { policy (Alastair Iain Johns- } \\
\text { ton, Andrew Scobell). }\end{array}$ \\
\hline
\end{tabular}

Source: Author's compilation.

Although the examination of China's Just War tradition can only shed light on a few aspects of contemporary Chinese foreign policy, it is still a bold attempt to generate additional incentives for the current analysis of China's foreign policy. Based on the examination of Just War in traditional China, we can only give suggestions about the correlation between Just War and the understanding of political order in traditional China. It follows that the traditional concept of order in China and its relevance for the contemporary view of order in the PRC needs to be examined more comprehensively. ${ }^{111}$

I also argue that the established IR theories' reference to the distinction between the international system and the unit (two-level game) cannot cope with China's future role in the world. Therefore, the perspective needs to be widened, with the introduction of the region as a new level of analysis. ${ }^{112}$ In the following paragraphs, I provide a short outline of how the surveyed characteristics of Just War could be applied to an analysis of China's contempo-

111 See the standard work written by Fairbank, John K. (ed.): The Chinese World Order. Traditional China's foreign relations, Cambridge 1968; Zhao, Suisheng: Power Competition in East Asia: from the old Chinese world order to postcold war regional multipolarity, London 1997. Oskar Weggel has already analyzed the future role of Confucian thought for the contemporary history of the PRC, see Weggel, Oskar: China im Aufbruch. Konfuzianismus und politische Zukunft, München 1997.

112 See for an overview Lake, David A./Morgan, Patrick M.: (eds.): Regional Order. Building Security in a New World, Pennsylvania 1997; Hurrell, Andrew/Louise Fawcett: Regionalism in world politics. Regional organizations and international order, Oxford 1997; Buzan, Barry/Ole Wæver: Regions and Powers. The structure of International Security, 4th printing, Cambridge 2006. 
rary foreign policy. Furthermore, the differentiation between the domestic, regional, and international levels will also be considered.

The traditional concept of authority was symbolized by the emperor, who represented the unity of harmony and stability within the Chinese empire. The emperor's claim to power was regionally unlimited. His virtue was the core of the Chinese traditional order and attracted the neighboring states; consequently, victory was to be gained without fighting. But the traditional Chinese self-perception of moral superiority collapsed with the Opium Wars. The "clash of civilizations" in the nineteenth century led to the end of the Mandate of Heaven, the abolishment of the tribute system, ${ }^{113}$ and the consolidation of a new political order with a particular focus on sovereignty. One of Mao Zedong's central achievements was the rehabilitation of the political order in the People's Republic of China. Ever since, national integrity has been one of the most important duties of Chinese policy. It has mostly been challenged by the Taiwan, Tibet, and Xinjiang questions. Beijing aims to avert the internationalization and spillover of these territorial conflicts to other neighboring regions.

On the international level, the Chinese government continues to support the principle of sovereignty. Beijing maintains a strict respect for noninterference in domestic affairs, especially in terms of authorizations within the scope of Chapter VII of the UN Charta. ${ }^{114}$ China's position in the report of the International Commission on Intervention and State Sovereignty, "Responsibility to Protect" (R2P), leaves no doubt about its primary orientation: stability. China argues, "It is inadvisable to make hasty judgements that the State concerned is unable to protect its own citizen and rush to intervene." 115 The primacy of stability in traditional China converges today with the classical paradigm of sovereignty on the international level.

The concept of a harmonious world underlies Chinese efforts to actively influence the international as well as regional order. This concept, introduced by Hu Jintao, constitutes a general change of policy in China, because Deng Xiaoping's reform policy was primarily domestically oriented. Deng's primary goal was to regain a stable economy. Therefore, his foreign policy followed the motto "hiding one's capacity while biding one's time" (taoguang yanghui yousuo zuowei). ${ }^{116}$ With the idea of a harmonious society and world, "Beijing is trying to synchronize its internal and external outlooks, so that its international behaviours are no more

113 See for further information on the Chinese Tribute system Fairbank, John K.: Trade and Diplomacy on the China Coast. The Opening of the Treaty Ports 1842-1854, Cambridge 1953 and Greenberg, Michael: British Trade and the Opening of China 1800-1842, Cambridge 1965 [1951].

114 See the overview by Ling, Bonny: China's Peacekeeping Diplomacy, in: International Relations and Institutions, No. 1 (2007), http://hrichina.org/public/PDFs/CRF.1.2007/CRF-2007-1_Peacekeeping.pdf, last accessed on 5 December 2007). For a recent analysis of China's attitude towards UN Peacekeeping Operations see He, Yin: China's Changing Policy on UN Peacekeeping Operations, in: Asia Studies (Institute for Security and Development Policy, Stockholm), July (2007), www.silkroadstudies.org/new/docs/Silkroadpapers/2007/YinHe0409073. pdf, last accessed on 5 December 2007); Gill, Bates/James Reilly: Sovereignty, intervention and Peacekeeping: The View from Beijing, in: Survival, Vol. 42, No. 3 (2000), pp. 41-59.

115 Overview of Member States' position, www.reformtheun.org/index.php?module=uploads\&func=download\& fileId=148, last accessed on 10 July 2008. Further information to R2P available at: www.iciss.ca/report-en.asp or www.responsibilitytoprotect.org/, last accessed on 10 July 2008.

116 Chin. 蹈光养晦有所作为. Also See ZHENG/TOK: Harmonious society and harmonious world. 
than extensions of its self-belief and domestic politics."117 Nevertheless, China's pursuit of dominance is still mainly dependent on its domestic strength, and its domestic development needs a peaceful and quiet international environment. Further, the establishment of a harmonious world depends on the particular political context. Internationally, China presents itself as a status quo power, but on the regional level, China seeks regional-power status by means of increased dependencies and regional engagement. Since the Asian financial crisis of 1997, a change in China's reputation in the region has been observable. As David Shambaugh states, "most nations in the region now see China as a good neighbour, a constructive partner, a careful listener, and a nonthreatening regional power." 118 China signed the ASEAN Treaty of Amity and Cooperation in 2003 and is also a member state of the East Asian Summit (EAS). This growing engagement as well as the economic dependence between ASEAN and China would increase the costs for the ASEAN member states in the event of a conflict were they to decide for the United States and against China. "China has made a concerted effort in the last decade to cultivate economic and security partners in Southeast Asia, reassuring nations that China's development presents long-term economic opportunities and does not threaten their security interests." 119 China's regional policy of "cooperative dependencies" seems to have successfully established a harmonious society in a harmonized region. In this respect, China certainly represents a rising power (see Chart 2).

\section{Chart 2: Levels of analysis in Modern and Traditional China}

\begin{tabular}{|l|l|l|}
\hline Level & \multicolumn{1}{|c|}{ Modern China } & \multicolumn{1}{|c|}{$\begin{array}{c}\text { Traditional China } \\
\text { (no difference between } \\
\text { internal and external relations) }\end{array}$} \\
\hline Domestic & $\begin{array}{l}\text { Harmony, } \\
\text { stability, } \\
\text { sovereignty, } \\
\text { national integrity }\end{array}$ & $\begin{array}{l}\text { Harmony converges with stability, } \\
\text { Harmony does not know boundaries, } \\
\text { Empire, } \\
\text { Peace = Harmony, } \\
\text { War = disturbance of harmony/stability }\end{array}$ \\
\hline Regional & $\begin{array}{l}\text { Rising power, } \\
\text { harmonized region, } \\
\text { economic interdependence }\end{array}$ & \\
\hline International & $\begin{array}{l}\text { Status quo power (stability), } \\
\text { sovereignty }\end{array}$ \\
\hline
\end{tabular}

Source: Author's compilation.

117 Zheng/Tok: Harmonious society and harmonious world, p. 6.

118 Shambaugh, David: China engages Asia. Reshaping the Regional Order, in: International Security, Vol. 29, No. 3 (2004/05), p. 64. Further, see the recent PEW Global Attitude June 2008, http://pewglobal.org/.

119 Meideiros, Evan S.: Strategic Hedging and the Future of Asia-Pacific Stability, in: The Washington Quarterly, Vol. 29, No. 1 (2005/06), p. 131. 


\section{Conclusion}

The correlation between harmony and stability is a central aspect of political thinking in traditional China. Peace is synonymous with harmony and describes the absence of disturbances. Consequently, the use of violence can be justified because the political order needs to be restored. Even though violence stands in contrast to the ideal of a virtuous emperor, wars in respect of order are Just Wars. Therefore, political order is the independent variable which determines whether the use of violence or war is justified.

The power of a Confucian emperor is regionally unlimited. Harmony does not know boundaries. The emphasis on boundaries, territory, and sovereignty distinguishes the modern Chinese state from the traditional Chinese empire. But the significance of a stable political order still determines political thinking in the PRC. On the international level, stability converges with the classic paradigm of sovereignty and China represents a status quo power. On the regional level, China seeks predominance and aims to build strategic dependencies by means of cooperation. Thus, China's rise and future political intentions need to be differentiated according to different levels of analysis. The connection between theories of regional order and established international relations theories might help to transcend the uncertainty about China's future political intentions.

As a result, the analysis of Just War in China could represent one way of shedding light on the ambiguity of Chinese foreign policy. It underlines why notions of China's peaceful development or the idea of a harmonious society/harmonious world are difficult to classify and foster the perception of Chinese politics as benign or malignant, depending on the level of analysis. However, the examination of the Chinese meaning of Just War only makes sense when it is analyzed in connection with the Chinese concept of political order. The importance of the traditional understanding of "order" in China has merely been introduced in this analysis; further research needs to deal in more detail with the Chinese perception of order and its relevance to the contemporary political intentions of the People's Republic of China. 


\section{Bibliography}

Adelmann, Jonathan R./Chih-yu: Symbolic War: The Chinese Use of Force. 1840-1980, Taipei 1993.

Al-Rhodan, Khalid R.: A critique of the China Threat Theory: A Systematic Analysis, in: Asian Perspective, Vol. 31, No. 2 (2007), pp. 41-66.

Augustinus: Vom Gottesstaat (transl. by Wilhelm Timme), 4th ed., 1997.

Bell, Daniel A.: Just War and Confucianism. Implications for the Contemporary World, in: Bell, Daniel A. (ed.): Confucian political ethics, Princeton 2007, pp. 226-257.

Bernstein, Richard/Ross H. Munro: China 1: The Coming Conflict with America, in: Foreign Affairs, Vol. 76, No. 2 (1997), pp. 18-32.

Billioud, Sébastian: Confucianism, "Cultural Tradition", and Official Discourse in China at the start of the New Century, in: China Perspectives, Vol. 69, No. 3 (2007), pp. 50-65.

Briant, Pierre: Histoire de l'empire Perse. De Cyrus à Alexander, Paris 1996.

Burles, Mark/Abram N. Shulsky: Patterns in China's Use of Force. Evidence from History and Doctrinal Writings, Washington 2000.

Buzan, Barry: People, States and Fear: an agenda for international security in the post-cold war era, 2nd edition, New York 1991.

Buzan, Barry/Ole Wæver: Regions and Powers. The structure of International Security, 4th edition, Cambridge 2006.

Christensen, Thomas J.: Posing Problems without Catching Up. China's Rise and Challenges for U.S. Security Policy, in: International Security, Vol. 25, No. 4 (2001), pp. 5-40.

Chung Chien-peng: Confronting Terrorism and Other Evils in China: All Quiet on the Western Front?, in: The China and Eurasia Forum Quarterly, Vol. 4, No. 2 (2006), pp. 75-87.

Confucius: Analects of Confucius, Beijing 1994; HSÜN-TZU (transl. by Hermann Köster), Kaldenkirchen 1967.

Creel, Herlee G.: The Origins of Statecraft in China (Vol. 1). The Western Chou Empire, Taipei 1970.

Davida, Kellogg E.: Jus post Bellum: The Importance of War Crime Trials, in: Parameters, Vol. 32, No. 3 (2002), pp. 87-99.

Fairbank, John K.: Introduction: Varieties of the Chinese Military Experience, in: Kiermann, Frank A./John K. Fairbank (ed.): Chinese Ways in Warfare, Cambridge Mass. 1974, pp. 1-26.

Fairbank, John K. (ed.): The Chinese World Order. Traditional China's foreign relations, Cambridge 1968.

Fairbank, John K.: Trade and Diplomacy on the China Coast. The Opening of the Treaty Ports 1842-1854, Cambridge 1953.

Fravel, Taylor M./Evan S. Medeiros: China's New Diplomacy, in: Foreign Affairs, Vol. 82, No. 6 (2003), pp. 22-35.

Friedberg, Aaron L.: The Future of U.S.-China Relations. Is Conflict Inevitable?, in: International Security, Vol. 30, No. 2 (2005), pp. 7-45. 
Gill, Bates: Rising China. China's New Security Diplomacy, Washington D.C. 2007.

Gill, Bates/Yanzhong Huang: Sources and Limits of Chinese "Soft Power", in: Survival, Vol. 48, No. 2 (2006), pp. 17-36.

Gill, Bates/James Reilly: Sovereignty, intervention and Peacekeeping: The View from Beijing, in: Survival, Vol. 42, No. 3 (2000).

Greenberg, Michael: British Trade and the Opening of China 1800-1842, Cambridge 1965 [1951].

Han Feizi: Die Kunst der Staatsführung. Die Schriften des Meisters Han Fei (transl. by Wilmar Mögling), Leipzig 1994.

Hobbes, Thomas: Leviathan: Oder Stoff, Form und Gewalt eines kirchlichen und bürgerlichen Staates (edited by Irene Fetscher), Frankfurt am Main 2006 [1651].

Hsü, Leonard S.: The Political Philosophy of Confucianism. An Interpretation of the Social and Political Ideas of Confucius, his Forerunners, and his early Disciples, London/ Dublin/New York 1932.

HSün-tzu (transl. by Hermann Köster), Kaldenkirchen 1967.

Hurrell Andrew/Louise Fawcett: Regionalism in world politics. Regional organizations and international order, Oxford 1997.

Johnston, Alastair I.: China as a Status Quo Power?, in: International Security, Vol. 27, No. 4 (2003), pp. 5-56.

Johnston, Alastair I.: Cultural Realism and Strategy in Maoist China, in: Peter J. Katzenstein (ed.): The Culture of National Security: Norms and Identity in Word Politics, New York 1996, pp. 216-268.

Johnston, Alastair I.: Cultural Realism. Strategic Culture and Grand Strategy in Chinese History, Princeton 1995.

Johnston, Alastair I.: Thinking about Strategic Culture, in: International Security, Vol. 19, No. 4 (1995), pp. 32-64.

Kane, Thomas M.: Inauspicious Tools: Chinese Thought on the Morality of Warfare, in: Robinson, P. (ed.): Just War in Comparative Perspective, Ashgate 2003, pp. 139-152.

Kang, David C.: China Rising. Peace, Power, and Order in East Asia, New York 2007.

Konfuzius: Gespräche (transl. by Ralf Moritz), Leipzig 1982.

Lam, Willy: Socialism with a Harmonious Face: Hu Jintao's Plan for Reform, in: China Brief, Vol. 4, No. 20 (2004), pp. 5-7.

Lake, David A./Patrick M. Morgan (eds.): Regional Order. Building Security in a New World, Pennsylvania 1997.

Lewis, Mark E.: The Just War in Early China, in: Torkel, B. (ed.): The Ethics of War in Asian Civilizations, London/New York 2006, pp. 185-200.

Lewis, Mark E.: Sanctioned Violence in Early China, Albany New York 1990.

Lintott, Andrew: Imperium Romanum. Politics and administration, London/New York 1993.

Mearsheimer, John: The Tragedy of Great Power Politics, New York 2001. 
Meideiro, Evan S.: Strategic Hedging and the Future of Asia-Pacific Stability, in: The Washington Quarterly, Vol. 29, No. 1 (2005/06), pp. 145-167.

Mo Ti: Gegen den Krieg (Mo Ti Schriften II) (transl. by Helwig Schmidt-Glintzer), Düsseldorf/Köln 1975.

Münkler, Herfried: Imperien: die Logik der Weltherrschaft - vom Alten Rom bis zu den Vereinigten Staaten, Hamburg 2007.

Orend, Brian: The Morality of War, Ontario 2006.

Orend, Brian: Jus Post Bellum, in: Journal of Social Philosophy, Vol. 31, No. 1 (2000), pp. 117-137.

Qin Yaoqing: Why there is no Chinese International Relations Theory?, in: International Relations of the Asia-Pacific, Vol. 7 No. 3 (2007), pp. 313-340.

Roy, Denny: Hegemon on the Horizon? China's Threat to East Asian Security, in: International Security, Vol. 19, No. 1 (1994), pp. 149-168.

Sawyer, Ralph D.: The Seven Military Classics of Ancient China (transl. by Ralph D. Sawyer with Mei-chün Sawyer), Boulder/San Francisco/Oxford 1993.

Scobell, Andrew: China's Use of Military Force. Beyond the Great Wall and the Long March, Cambridge 2003.

Scobell, Andrew: The Chinese Cult of Defense, in: Issues \& Studies, Vol. 37, No. 5 (2001), pp. 100-127.

Segal, Gerald: Does China Matter?, in: Foreign Affairs, Vol. 78, No. 5 (1999), pp. 24-36.

Shang Yang: The Book of Lord Shang. A Classic of the Chinese School of Law (transl. by Duyvendak), London 1928.

Shambaugh, David: China engages Asia. Reshaping the Regional Order, in: International Security, Vol. 29, No. 3 (2004/05), pp. 64-99.

Sun Pin: Military Methods (transl. by Ralp D. Sawyer with Mei-chün Sawyer), Boulder/San Francisco/Oxford 1995.

Sun Tsu: Wahrhaft siegt, wer nicht kämpft (transl. by Ingrid Fischer-Schreiber), Freiburg 1990.

Sun Tzu: The Art of War (transl. by. Samuel B. Griffith), Oxford 1963.

Swaine, Michael D./Ashley J. Tellis: Interpreting China's Grand Strategy. Past, Present, and Future (Project Air Force RAND), Santa Monica 2000.

Turner, Karen: War, Punishment and The Law of nature in Early Chinese Concepts of the State, in: Harvard Journal of Asiatic Studies, Vol. 53, No. 2 (1993), pp. 285-324.

Walzer, Michael: Just and Unjust Wars. A Moral Argument with Historical Illustrations, 3rd edition, New York 2003.

Waltz, Kenneth N.: Man, the state and war. A Theoretical Analysis, New York 2001 [1959].

Weggel, Oskar: China im Aufbruch. Konfuzianismus und politische Zukunft, München 1997.

Zhang, Dainian: Key Concepts in Chinese Philosophy (transl. and ed. by Edmund Ryden), New Haven/London 2002, pp. 3-11.

Zhang, Tiejun: Reconstruction the Great Wall. Chinese Security Strategy in the Early 21st Century, Goteborg 2003. 
Zhao, Suisheng: Power Competition in East Asia: from the old Chinese world order to postcold war regional multipolarity, London 1997.

Zheng, Yongniang/Sow Keat Tok: Harmonious society and harmonious world: China's policy discourse under $\mathrm{Hu}$ Jintao, in: Briefing Series (University of Nottingham), 1-9.

\section{Chinese Resources}

宫玉振 (Gong Yuzheng): 文化流变与中国传统兵家的形态更替 (Cultural Transformation and the Substitution of the Chinese Traditional Military Theory), in: 军事历史研究 (Military Historical Record), No. 1 (2000), pp. 172-180.

孟子 (Mengzi), in: 陈成国 (Chen Chengguo): 四书五经 (Four Books and Five Classics) (Vol. 1), Hunan Changshao 2002, pp. 61-139.

楼春豪 (Lou Chunhao): 进攻性现实主义“中国威胁论”的实质 (The Essence of the Offensive

Realism view on the „China Threat Debate"), in: 国际关系学院研究生部 (Journal of University of International Relations), No. 3 (2006), pp. 14-18.

罗建波 (Luo Jianbo): 构建中国崛起的对外文化战略 (Establishing an external cultural strategy currently rising in China), in: 现代国际关系 (Contemporary International Relations), No. 3 (2006).

孟子 (Mengzi), in: 陈成国 (Chen Chengguo): 四书五经 (Four Books and Five Classics) (Band 1), Hunan Changshao 2002.

倪乐雄 (Ni Lexiong): 孔子与战争 (Confucius and War), in: 军事历史研究 (Military Historical Record), No. 4 (1999), pp. 93-104.

桑东辉 (Sang Donghui): 也谈春秋战国时期的诸侯国是否为主权国家. 以《墨子》为例, 以国

际法为视角 (From the perspective of International Law using Mozi as an example: The renewed discussion about whether the Feudal States of the Chunqiu and Warring States Period represent Sovereign States or not), in: 国际政治研究 (Studies of International Politics), No. 2 (2006), pp. 137-149.

时殷弘 (Shi Yinhong): 关于战争与和平的伦理传统: 西方与中国 (Theoretical Tradition of War

and Peace. China and the West), in: 世界经济与政治 (World Economics and Politics), No. 10 (1999).

孙学峰(Sun Xuefeng): 和谐世界理念与中国国际关系理论研究 (The concept of a harmonious world and the study of Chinese international relation theory), in: 教学与研究 (Education and Research), Vol. 11, 2007.

王联斌 (Wang Lianbin): 中华武德文化研究论纲 (Theory Outline of the Chinese Military Virtue Culture Research), in: 军事历史研究 (Military Historical Record) No. 4 (2005), pp. 150-159.

吴征宇 (Wu Zengyu): 正义战争理论的当代意义论析 (Contemporary Meaning of the Just War

Theory), in: 现代国际关系 (Contemporary International Relations), No. 8 (2004), pp. 12-17. 姚有志 (Yao Youzhi)/马德宝 (Ma Debao): 《孙子兵法》与当代中国主流战争理论 (Sun Zi's

Art of War and Mainstream Contemporary Chinese Theories of War), in: 中国军事科学 (China Military Science), No. 6 (2004), pp. 9-16. 
于泽民 (Yu Zemin): 两千年军事思想的沟通. 中国古典战略今用 (The Understanding of 2000 Years Chinese Military Thought. The Present Usage of Classical Chinese Strategy), Beijing 2006.

张露 (Zhang Lu): 中西正义战争思想比较分析 (A Comparison of Chinese and Western Just War Thought), in: 现代国际关系 (Contemporary International Relations), No. 4 (2005), pp. 15-20.

周振甫 (Zhou Zhenfu): 古代战纪选 (A Selection of Classical War Records), Nanjing 2005.

朱之江 (Zhu Zhijiang): 论道德视角下的战争 (Discussion about war from a moral viewpoint), in: 军事历史研究(Military Historical Research), Nr. 1 (2005), pp. 142-152.

左高山 (Zuo Gaoshan): 正义的战争与战争的正义. 关于战争伦理的反思 (Just War and Justice of War. About the recollection of war morality), in: 伦理学研究 (Studies in Ethics), No. 6 (2005), pp. 43-48.

\section{Internet Resources}

Annual Report to Congress: Military Power of the People's Republic of China 2008; all reports from 2002 to 2008 available at: www.defenselink.mil/pubs/china.html.

Carnegie Endowment for International Peace: Reframing China Policy. China's Strategic Objectives in Asia. Discussion with Aaron Friedberg and Robert Sutter (Moderator: Michael Swaine), 2007, www.carnegieendowment.org/files/debate_five.pdf.

Harmonious Society, in: China Daily, 29. September 2007, http://english.peopledaily.com.cn/ 90002/92169/92211/6274603.html.

He, Yin: China's Changing Policy on UN Peacekeeping Operations, in: Asia Studies (Institute for Security and Development Policy, Stockholm), July (2007), www.silkroadstudies.org/ new/docs/Silkroadpapers/2007/YinHe0409073.pdf.

Li Zhaoxing: Peace, Development and Cooperation. Banner for China's Diplomacy in the New Era, 08/2005, www.fmprc.gov.cn/eng/zxxx/t208032.htm.

Ling, Bonny: China's Peacekeeping Diplomacy, in: International Relations and Institutions, No. 1 (2007), http://hrichina.org/public/PDFs/CRF.1.2007/CRF-2007-1_Peacekeeping.pdf.

Ministry of Foreign Affairs of the People Republic of China: Peace, Development and Cooperation. In Commemoration of the 35th Anniversary of Restoration of Lawful Seat of the People's Republic of China in the United Nations, 2006, www.fmprc.gov.cn/ng/wjb/zzjg/ gjs/gjsxw/t278484.htm.

The PEW Global Attitudes Project: Global Economic Gloom - China and India Notable Exceptions, June 2008, http://pewglobal.org/reports/pdf/260.pdf.

中国的和平发展道路 (China's Way of Peace and Development), www.gov.cn/zwgk/2005-12/22/ content_134060.htm.

www.china.com.cn/aboutchina/zhuanti/hxsh/node_7043253.htm.

www.iciss.ca/report-en.asp.

www.reformtheun.org/index.php?module=uploads\&func=download\&fileId=148.

www.responsibilitytoprotect.org/. 


\section{GIGA Journal Family}

The GIGA journal family is a unique publishing initiative that brings together five international area journals edited by the GIGA German Institute of Global and Area Studies.

The journals are high-standard venues for original research on and empirically sound analysis of contemporary politics, society and the economy in Africa, China, Latin America, the Middle East, and Southeast Asia.

- Africa Spectrum

(3 issues per year)

- Journal of Current Chinese Affairs - China aktuell

(4 issues per year)

- Journal of Current Southeast Asian Affairs

(4 issues per year)

- JPLA - Journal of Politics in Latin America

( 3 issues per year)

Further information at www.giga-hamburg.de/giga-journal-family

Articles also available online

\section{GIGA German Institute of Global and Area Studies}

Leibniz-Institut für Globale und Regionale Studien

Neuer Jungfernstieg 21 - 20354 Hamburg - Germany

Phone: +49 40 42825-594 - Fax: +49 40 42825-547

E-mail: info@giga-hamburg.de

Homepage: www.giga-hamburg.de

Ask for your personal sample copy.

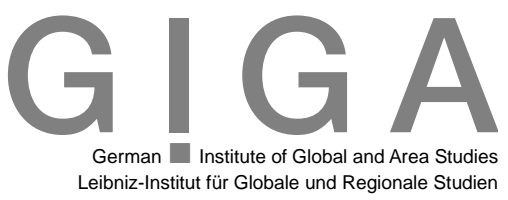




\section{G

\section{Recent Issues}

No 87 Andreas Mehler: Breaking the "Insecurity Trap"? How Violence and Counter-violence Are Perpetuated in Elite Power Struggles; September 2008

No 86 Jan Peter Wogart, Gilberto Calcagnotto, Wolfgang Hein, Christian von Soest: AIDS, Access to Medicines, and the Different Roles of the Brazilian and South African Governments in Global Health Governance; September 2008

No 85 Juliane Brach: Constraints to Economic Development and Growth in the Middle East and North Africa; September 2008

No 84 Sebastian Huhn: A History of Nonviolence: Insecurity and the Normative Power of the Imagined in Costa Rica; August 2008

No 83 Andreas Mehler: Not Always in the People's Interest: Power-sharing Arrangements in African Peace Agreements; July 2008

No 82 Dirk Kohnert: EU-African Economic Relations: Continuing Dominance Traded for Aid?; July 2008

No 81 Sebastian Huhn: Discourses on Violence in Costa Rica, El Salvador, and Nicaragua: Social Perceptions in Everyday Life; June 2008

No 80 Peter Peetz: Discourses on Violence in Costa Rica, El Salvador, and Nicaragua: Youth, Crime, and the Responses of the State; June 2008

No 79 Sandra Destradi: Empire, Hegemony, and Leadership: Developing a Research Framework for the Study of Regional Powers; June 2008

No 78 Esther K. Ishengoma and Robert Kappel: Business Constraints and Growth Potential of Micro and Small Manufacturing Enterprises in Uganda; May 2008

No 77 Miriam Prys: Developing a Contextually Relevant Concept of Regional Hegemony: The Case of South Africa, Zimbabwe and "Quiet Diplomacy"; May 2008

No 76 Anika Oettler: Do Qualitative Data Help in Addressing Central American Violence? Research Note on Data Collection; May 2008

No 75 Andreas Mehler, Ulf Engel, Lena Giesbert, Jenny Kuhlmann, Christian von Soest: Structural Stability: On the Prerequisites of Nonviolent Conflict Management; April 2008

No 74 Andreas Ufen: The Evolution of Cleavages in the Indonesian Party System; April 2008

No 73 Thomas Kern and Sang-Hui Nam: Social Movements as Agents of Innovation: Citizen Journalism in South Korea; April 2008

All GIGA Working Papers are available free of charge at www.giga-hamburg.de/workingpapers. For any requests please contact: workingpapers@giga-hamburg.de.

Editor of the Working Paper Series: Martin Beck 